\title{
Adaptive Response of Listeria monocytogenes to the Stress Factors in the Food Processing Environment
}

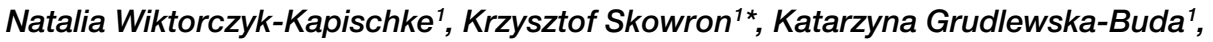 \\ Ewa Wałecka-Zacharska ${ }^{2}$, Jakub Korkus ${ }^{2}$ and Eugenia Gospodarek-Komkowska ${ }^{1}$ \\ 'Department of Microbiology, L. Rydygier Collegium Medicum in Bydgoszcz, Nicolaus Copernicus University in Toruń, \\ Bydgoszcz, Poland, ${ }^{2}$ Department of Food Hygiene and Consumer Health, Wrocław University of Environmental and Life \\ Sciences, Wrocław, Poland
}

Listeria monocytogenes are Gram-positive, facultatively anaerobic, non-spore-forming bacteria that easily adapt to changing environmental conditions. The ability to grow at a

OPEN ACCESS

Edited by:

Fatih Ozogul,

Çukurova University, Turkey

Reviewed by:

Sandra Sousa,

Universidade do Porto, Portugal

Heena Sharma,

National Dairy Research Institute

(ICAR), India

*Correspondence:

Krzysztof Skowron

skowron238@wp.pl

Specialty section: This article was submitted to Food Microbiology,

a section of the journal

Frontiers in Microbiology

Received: 15 May 2021

Accepted: 22 July 2021

Published: 19 August 2021

Citation:

Wiktorczyk-Kapischke N, Skowron K, Grudlewska-Buda K,

Wałecka-Zacharska E, Korkus J and Gospodarek-Komkowska E (2021)

Adaptive Response of Listeria

monocytogenes to the Stress Factors in the Food Processing Environment.

Front. Microbiol. 12:710085.

doi: 10.3389/fmicb.2021.710085 wide range of temperatures, $\mathrm{pH}$, and salinity determines the presence of the pathogen in water, sewage, soil, decaying vegetation, and animal feed. L. monocytogenes is an etiological factor of listeriosis, especially dangerous for the elderly, pregnant women, and newborns. The major source of $L$. monocytogenes for humans is food, including fresh and smoked products. Its high prevalence in food is associated with bacterial adaptation to the food processing environment (FPE). Since the number of listeriosis cases has been progressively increasing an efficient eradication of the pathogen from the FPE is crucial. Understanding the mechanisms of bacterial adaptation to environmental stress will significantly contribute to developing novel, effective methods of controlling L. monocytogenes in the food industry.

Keywords: Listeria monocytogenes, stress factors, adaptive response, disinfectants, food processing environment

\section{INTRODUCTION}

Listeria monocytogenes are Gram-positive, rod-shaped, non-spore-forming bacteria, widespread in the environment, i.e., water, soil, sewage, decaying vegetation, silage, and animals (O’Neil and Marquis, 2006; Gandhi and Chikindas, 2007). These bacteria tolerate low water activity $(\geq 0.9)$ and are able to survive in a wide range of temperature $\left(0-45^{\circ} \mathrm{C}\right), \mathrm{pH}(4.3-9.6)$, and salinity (up to $10 \% \mathrm{NaCl}$; Renier et al., 2011). L. monocytogenes is a causative agent of human listeriosis, especially dangerous for the elderly, pregnant women, newborns, and immunocompromised patients. The major source of the pathogen for humans is food, including meat, fish (raw and smoked), mold cheese, unpasteurized milk, ready-to-eat (RTE) food, and fresh produce (Gandhi and Chikindas, 2007). Despite the low annual incidence of listeriosis ranging from 0.1 to 10 cases per million people, the mortality rate is high and may exceed 15-20\% (World Health Organization (WHO), 2018a). To date, many listeriosis outbreaks have been noted worldwide, including the deadliest outbreak in United States history (1985 - soft cheese; Beckers et al., 1987), the deadliest outbreak in Canada (2008 - deli meat; Birk-Urovitz, 2011), and the deadliest 
outbreak ever in South Africa (2017-2018, deli meat; Smith et al., 2019). Table 1 summarizes data on the most important epidemics of listeriosis. Despite the development of therapies and biocontrol measures, L. monocytogenes remains a serious threat to food safety, as evidenced by the outbreak in South Africa. Environmental stress affects the morphology, pathogenicity, gene expression, and antimicrobial resistance (AMR) of $L$. monocytogenes (Matereke and Okoh, 2020). Understanding the adaptive mechanisms of the pathogen can facilitate the planning of disinfection strategies (more effective and less expensive methods) in a food processing environment (FPE), thus ensuring food safety.

The review aims to summarize knowledge about the stress response of L. monocytogenes in FPE. A deeper insight into the stress response of L. monocytogenes may help implement well-designed food preservation and disinfection protocols, reducing the risk of the bacteria in the food and FPE and ensuring consumer safety.

\section{STRESS FACTORS IN THE FOOD PROCESSING ENVIRONMENT}

Listeria monocytogenes is a serious problem in the food industry as the pathogen easily contaminates a variety of food products leading to food recall (Miladi et al., 2017). In FPE, L. monocytogenes encounters many adverse stress factors, e.g., low/high temperature, low $\mathrm{pH}$, high salinity, and the concentration of chemicals, which may be sublethal or lethal (Figure 1).

Environmental stress tolerance and virulence may be considered as overlapping aspects of the biology of L. monocytogenes (O'Byrne and Karatzas, 2008). Without a strong stress response, the pathogen would not survive and persist in the FPE and withstand the passage through the human gastrointestinal tract (NicAogain and O'Byrne, 2016). One of the major stress response mechanisms is associated with alternative sigma factors $\sigma^{\mathrm{B}}, \sigma^{\mathrm{C}}, \sigma^{\mathrm{H}}$, and $\sigma^{\mathrm{L}}$, of which $\sigma^{\mathrm{B}}$ plays the pivotal role (Lungu et al., 2009). In L. monocytogenes, these factors control over 300 genes, including stress-associated and virulence genes. $\sigma^{\mathrm{B}}$ helps L. monocytogenes survive under acid, osmotic, oxidative, and other stress conditions (Figure 2). The activity of $\sigma^{\mathrm{B}}$ and hence the general stress response activation in L. monocytogenes, is regulated by a complex structure known as the stressosome (NicAogain and O'Byrne, 2016). Analyses of the proteome and transcriptome of $L$. monocytogenes revealed many proteins activated in response to stress. Table 2 presents an overview of L. monocytogenes main stress-response and virulence genes and proteins.

$\sigma^{\mathrm{B}}$ is responsible for the transcription of genes involved in the stress response. In turn, PrfA (transcriptional activator of virulence genes) controls the expression of virulence genes. There is an extensive cross-talk system between $\sigma^{\mathrm{B}}$ and PrfA ensuring the optimal expression of genes required in extrahost environments (including suppression of genes that reduce efficiency) and in intrahost environments (Gaballa et al., 2019). The stress conditions encountered during food production and the adaptive response of $L$. monocytogenes affect the virulence of the bacilli and thus pose a much higher risk to consumers. The knowledge on the adaptive mechanisms of $L$. monocytogenes to the changing environmental conditions will help design appropriate methods of production process control and disinfection (mainly lethal effect). As a result, we expect to limit the acquisition of resistance and prevent the increase of virulence of L. monocytogenes.

The presented review focuses on the stress factors encountered by L. monocytogenes in FPE and the stress response mechanisms.

\section{Salt}

One of the main preservatives in FPE is salt contributing to osmotic stress. Salt is frequently used in the food industry as a preservative and antibacterial agent, especially in RTE meat and fish products (Desmond, 2006). In addition, salt is widely used as a texture and flavor improver (Ruusunen and Puolanne, 2005). Salt disturbs homeostasis between the internal and external environment of the bacterial cells. All changes of the osmolarity induce osmotic stress resulting in hypotonia (swelling of the cell) or hypertonia (shrinking of the cell; Sleator and Hill, 2002). The change of osmolarity may also affect biophysical properties (surface tension), decrease cell membrane fluidity, and destroy proteins and DNA. Moreover, salt can contribute to bacterial cell desiccation, making it vulnerable to the action of free radicals, which results in cell death. Reversely, osmotic stress may lead to cross-resistance and help bacteria survive in the next stage of food processing (Burgess et al., 2016).

Listeria monocytogenes can withstand up to $10 \%$ of $\mathrm{NaCl}$ in the environment (Chihib et al., 2003). Many proteins play role in salt stress response, including osmolyte transporters, cell wall modifying proteins, regulatory proteins, and general stress response proteins (Figure 3). The response to increased osmolality in $L$. monocytogenes is two-step. First, $\mathrm{K}^{+}$and glutamate are collected, and then the accumulation of compatible solutes/osmolytes occurs. Compatible solutes are small organic molecules that function as osmoprotectants and are indispensable for cell turgor maintenance. In response to elevated osmolarity, bacterial cell accumulates very high levels of compatible solutes (restoring the cell turgor without the influence on the cytoplasmic functions). Additionally, compatible solutes stabilize the structure and functions of enzymes under stress conditions (Matereke and Okoh, 2020). A number of osmolytes have been identified in L. monocytogenes, e.g., glycine betaine, carnitine, proline, acetylcarnitine, gammabutyrobetaine, and dimethylsulfoniopropionate. Since these bacteria are unable to synthesize osmolytes de novo they must be transported from the environment. L-carnitine is commonly found in raw meat, whereas vegetables (sugar beet and spinach) and cornflakes are sources of glycine betaine (Chan et al., 2007).

The analysis of $L$. monocytogenes genome revealed three $\sigma^{\mathrm{B}}$-dependent transporters of compatible solutes, i.e., betaine symporter (BetL), Gbu, and OpuC (Figure 3; Bucur et al., 2018). Glycine betaine accumulation in the cytosol may occur without impairing protein structure and enzyme-substrate interaction (Angelidis and Smith, 2003). There are two 
TABLE 1 | The most important epidemics of listeriosis.

\begin{tabular}{|c|c|c|c|c|c|c|c|}
\hline & Year & Country & Food & $\begin{array}{l}\text { Number } \\
\text { of cases }\end{array}$ & $\begin{array}{l}\text { Number } \\
\text { of deaths }\end{array}$ & $\begin{array}{l}\text { Number of } \\
\text { miscarriages }\end{array}$ & References \\
\hline \multirow{22}{*}{ United States } & 1985 & Los Angeles & Mexican-style cheese & 142 & 41 & 0 & Beckers et al., 1987 \\
\hline & 1998-1999 & 11 states & Hot dog & 108 & 14 & 4 & Centers of Disease Control and Prevention (CDC), 1999 \\
\hline & 2000 & 10 states & Deli turkey meat & 29 & 4 & 3 & Centers of Disease Control and Prevention (CDC), 2000 \\
\hline & 2002 & Eight states & $\begin{array}{l}\text { Fresh and frozen, Ready-to-eat } \\
\text { turkey, and chicken }\end{array}$ & 46 & 7 & 3 & Centers of Disease Control and Prevention (CDC), 2002 \\
\hline & 2010 & Texas & Pre-cut celery & 10 & 5 & 0 & Gaul et al., 2012 \\
\hline & 2011 & 28 states & Cantaloupe & 147 & 33 & 1 & Centers of Disease Control and Prevention (CDC), 2012a \\
\hline & 2012 & 13 states & Ricotta salata Cheese & 22 & 4 & 1 & Centers of Disease Control and Prevention (CDC), 2012b \\
\hline & 2013 & Five states & $\begin{array}{l}\text { Crave brothers farmstead } \\
\text { cheeses }\end{array}$ & 6 & 1 & 1 & Centers of Disease Control and Prevention (CDC), 2012c \\
\hline & 2010-2015 & Four states & Blue bell ice cream & 10 & 3 & 0 & Centers of Disease Control and Prevention (CDC), 2015a \\
\hline & 2015 & 10 states & $\begin{array}{l}\text { Soft cheeses distributed by } \\
\text { Karoun dairies }\end{array}$ & 30 & 3 & 1 & Centers of Disease Control and Prevention (CDC), 2015b \\
\hline & $2014-2015$ & 12 states & Caramel apples & 35 & 7 & 1 & Centers of Disease Control and Prevention (CDC), 2015c \\
\hline & 2016 & Two states & Raw milk & 2 & 1 & 0 & Centers of Disease Control and Prevention (CDC), 2016a \\
\hline & 2016 & Four states & Frozen vegetables & 9 & 3 & 0 & Centers of Disease Control and Prevention (CDC), 2016b \\
\hline & 2016 & Nine states & Packaged salads & 19 & 1 & 0 & Centers of Disease Control and Prevention (CDC), 2016c \\
\hline & 2017 & Four states & $\begin{array}{l}\text { Soft raw milk cheese } \\
\text { Made by vulto creamery }\end{array}$ & 8 & 2 & 0 & Centers of Disease Control and Prevention (CDC), 2017 \\
\hline & 2018 & Two states & Deli ham & 4 & 1 & 0 & Centers of Disease Control and Prevention (CDC), 2018 \\
\hline & 2019 & Five states & Deli-sliced meats and cheeses & 10 & 1 & 0 & Centers of Disease Control and Prevention (CDC), 2019a \\
\hline & 2019 & Four states & Pork products & 4 & 0 & 0 & Centers of Disease Control and Prevention (CDC), 2019b \\
\hline & 2019 & Five states & Hard-boiled eggs & 8 & 1 & 0 & Centers of Disease Control and Prevention (CDC), 2020a \\
\hline & 2020 & 17 states & Enoki mushrooms & 36 & 4 & 2 & Centers of Disease Control and Prevention (CDC), 2020b \\
\hline & 2020 & Four states & Deli meats & 12 & 1 & 0 & Centers of Disease Control and Prevention (CDC), 2021a \\
\hline & 2021 & Four states & Queso Fresco & 11 & 1 & 0 & Centers of Disease Control and Prevention (CDC), 2021b \\
\hline \multirow{7}{*}{ Europe } & 2003 & $\begin{array}{l}\text { The Swindon area } \\
\text { of the United Kingdom }\end{array}$ & $\begin{array}{l}\text { Prepacked sandwiches from a } \\
\text { retail outlet }\end{array}$ & 5 & 0 & 0 & Dawson et al., 2006 \\
\hline & 2005 & Switzerland & $\begin{array}{l}\text { Soft cheese (known as } \\
\text { "tomme") }\end{array}$ & 10 & 3 & 2 & Bille et al., 2006 \\
\hline & $2015-2018$ & $\begin{array}{l}\text { Austria, Denmark, Finland, } \\
\text { Sweden, and the United Kingdom }\end{array}$ & Frozen corn & 41 & 6 & 0 & European Centre for Disease Prevention and Control (ECDC), 2018a \\
\hline & $2017-2019$ & Netherlands, Belgium & Ready-to-eat meat products & 21 & 3 & 1 & European Centre for Disease Prevention and Control (ECDC), 2019a \\
\hline & Sience 2015 & Denmark, Germany, and France & Ready-to-eat salmon products & 12 & 4 & 0 & European Centre for Disease Prevention and Control (ECDC), 2018b \\
\hline & $2014-2019$ & $\begin{array}{l}\text { Denmark, Estonia, Finland, } \\
\text { France, and Sweden }\end{array}$ & Cold-smoked fish products & 22 & 5 & 0 & European Centre for Disease Prevention and Control (ECDC), 2019b \\
\hline & 2019 & Spain & $\begin{array}{l}\text { Chilled roasted pork meat } \\
\text { product }\end{array}$ & 222 & 3 & 6 & World Health Organization (WHO), 2018b \\
\hline Australia & 2018 & Australia & Rockmelons & 20 & 7 & 1 & World Health Organization (WHO), 2018c \\
\hline Africa & $2017-2018$ & Republic of South Africa & $\begin{array}{l}\text { Ready-to-eat processed meat } \\
\text { products }\end{array}$ & 1,024 & 200 & - & Smith et al., 2019 \\
\hline
\end{tabular}




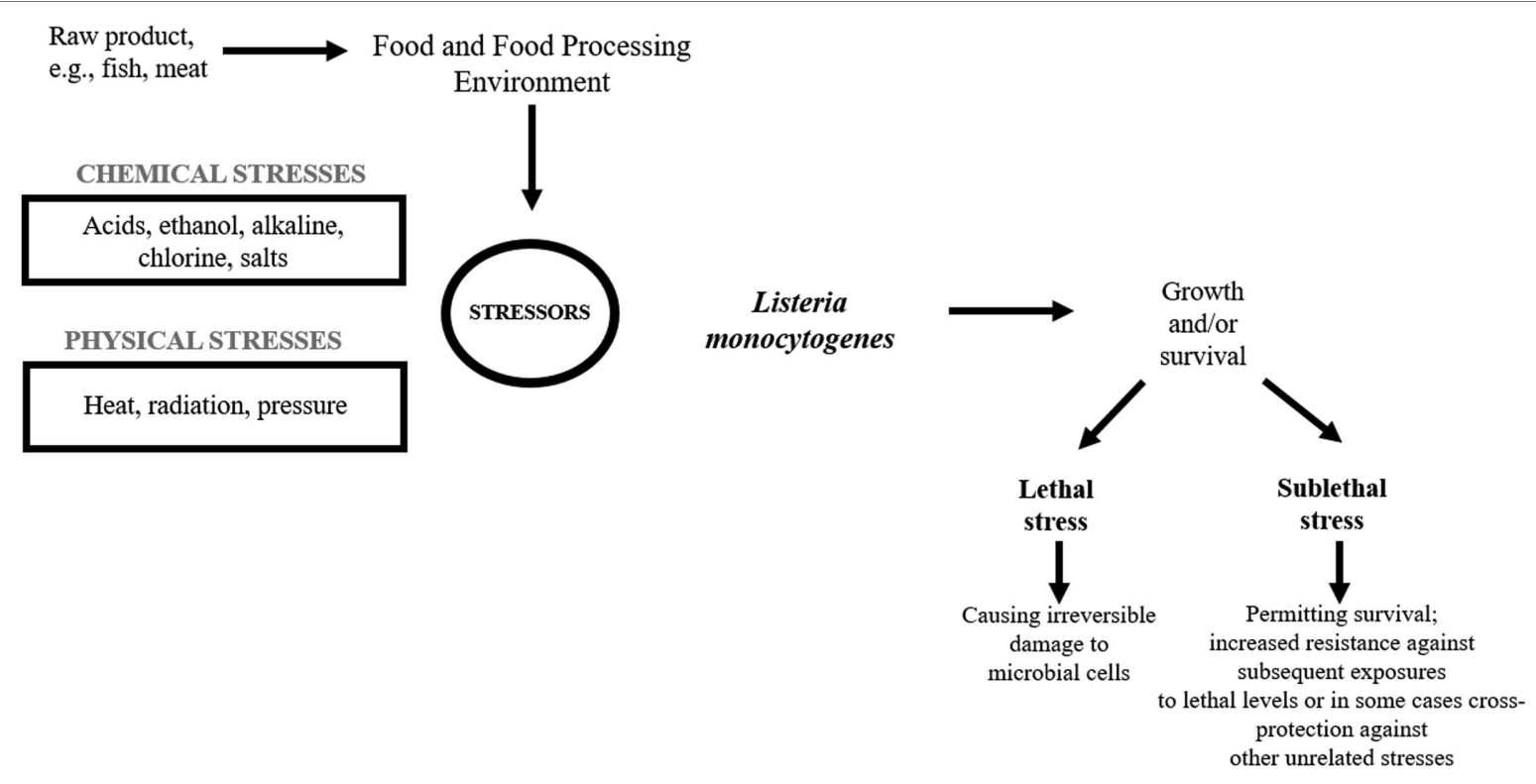

FIGURE 1 | Listeria monocytogenes in the food processing environment.

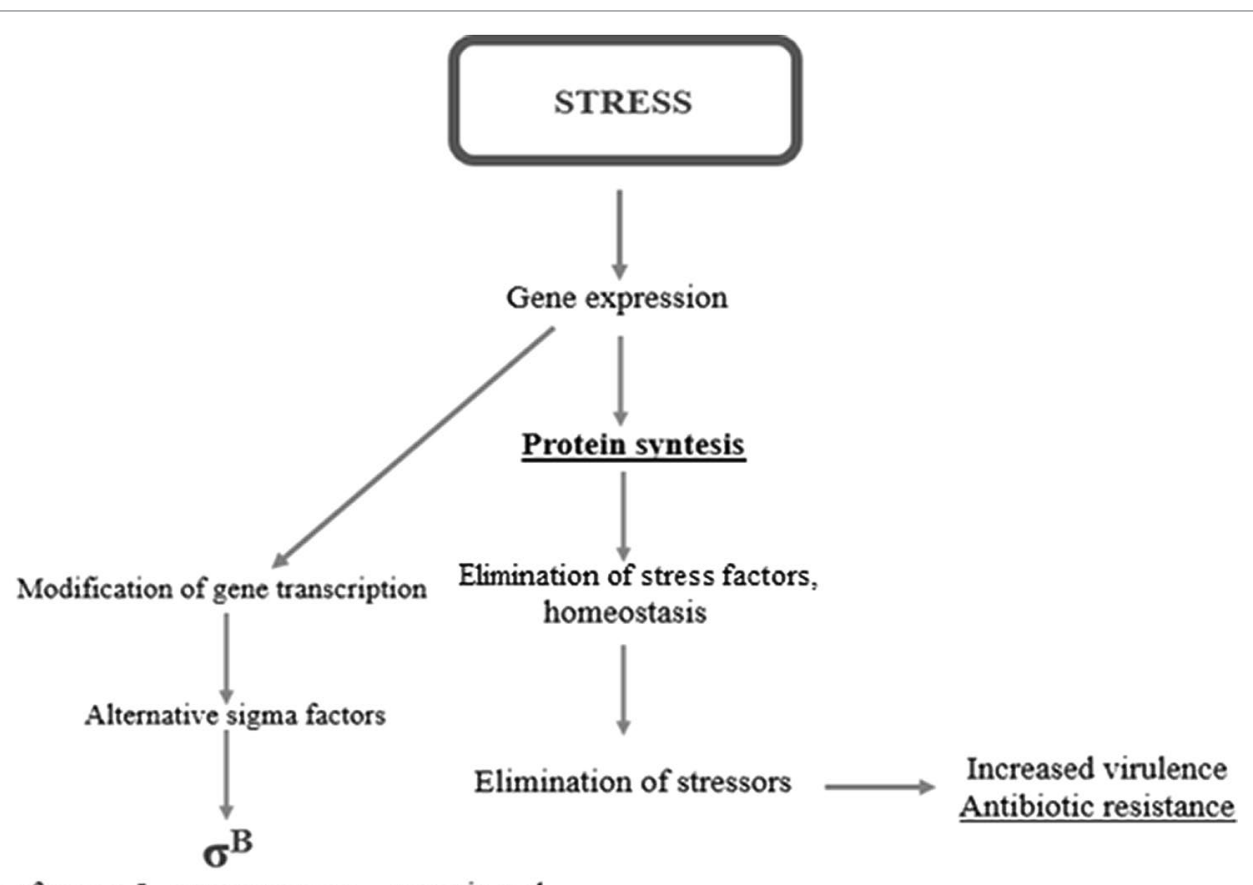

Expression of genes L. monocytogenes - osmotic and oxidative stress, low and high temperature, low $\mathrm{pH}$, high hydrostatic pressure, high concentration of ethanol

FIGURE 2 | The stress response in L. monocytogenes.

transporters of glycine betaine, i.e., ATP-dependent porter II (Gbu) and $\mathrm{Na}^{+}$- glycine BetL. BetL, encoded by betL gene, is activated immediately upon stress exposure but provides longterm protection only under low salt stress. In turn, Gbu, encoded by $g b u A B C$ operon, plays the predominant role in long-term adaptation, especially at higher concentrations of salt (Mendum and Smith, 2002). OpuC, encoded by opuCABCD operon, is an ATP-dependent carnitine transporter activated in response to osmotic and cold stress (Figure 3; Bucur et al., 2018). In the absence of osmoprotectants, the osmotic stress 
TABLE 2 | Listeria monocytogenes stress-response and virulence genes and proteins.

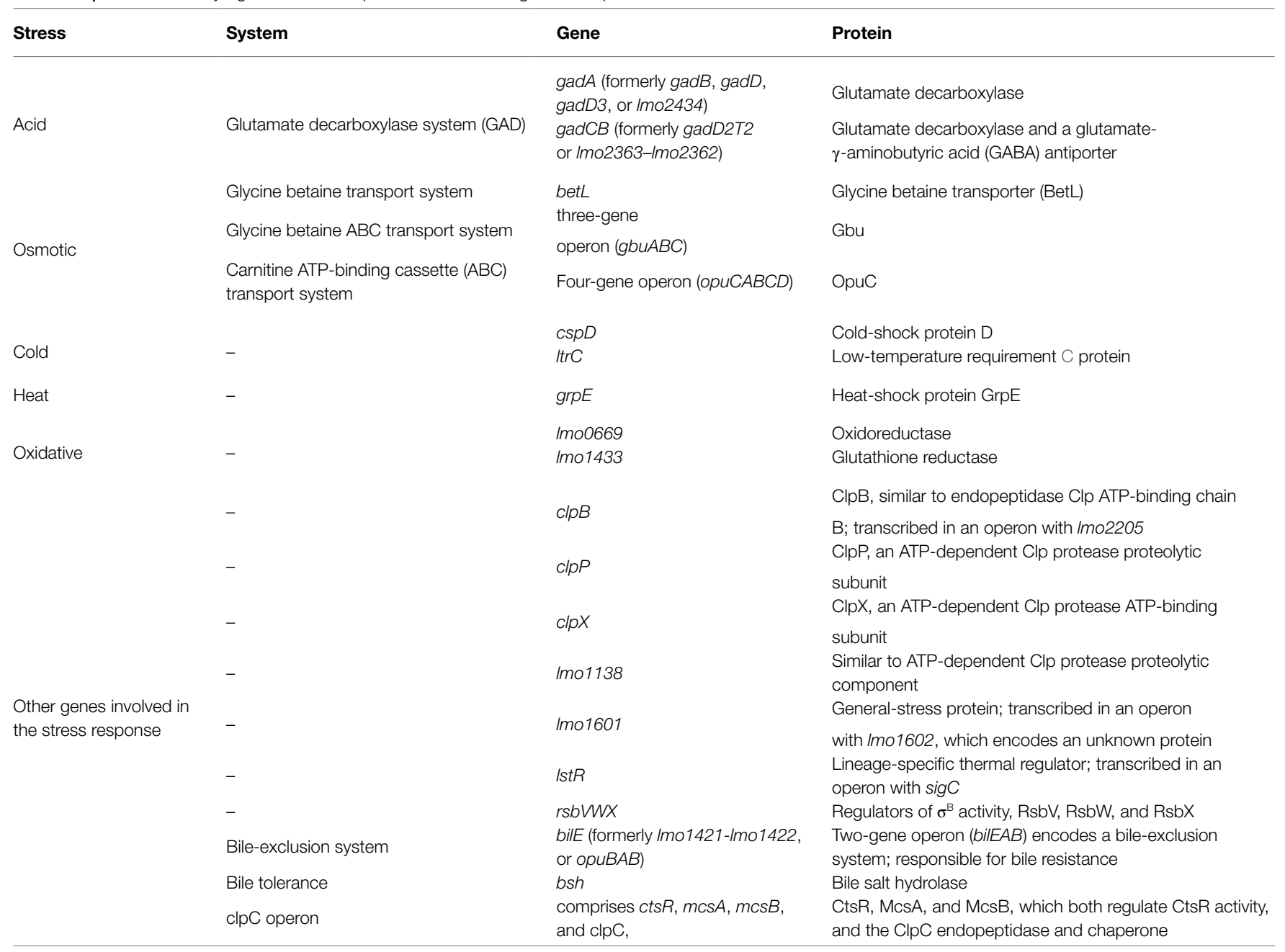

response mechanism stress relies on Ctc protein. Ctc most likely binds to the 5S RNA sub-principle (Duché et al., 2002).

An important role in osmotolerance plays also general stress response proteins, including serine protease HtrA (degradation of improperly folded proteins), two-component regulatory system LisRK, ClpC (ATPase), CLpP (protease), and RelA (synthesis of guanosine pentaphosphate [(p)ppGpp]), Ctc. Researchers have suggested that RelA is involved in osmotic stress response independent of compatible solutes accumulation (Burall et al., 2012).

In $\sigma^{\mathrm{B}}$ regulon, scientists have described eight genes encoding putative osmotic stress-associated proteins, i.e., $L M R G 01658$, LMRG 00208, LMRG 00211-00212, hfq, and $d t p T$ in L. monocytogenes. However, the role of these genes has not been elucidated yet (Liu et al., 2019). Ribeiro et al. (2014) have suggested that under salt stress, upregulation of these genes enables the increased synthesis of exopolysaccharides. The Hfq protein binds sRNA during intracellular growth. The mutants devoid of this protein were not able to respond properly to osmotic and ethanol stress (Christiansen et al., 2006). The DtpT protein plays important role in the transport of di- and tripeptides involved in osmotic stress protection (Wouters et al., 2005). In turn, Kdp is a transcriptional response regulator enabling quick reaction to stress via $\mathrm{K}^{+}$ import. Also, trehalose was reported to be linked to osmotolerance, and the treA gene, encoding phosphotrehalase was detected in L. monocytogenes (Ells and Truelstrup Hansen, 2011). Researchers described proteins modifying cell membrane, i.e., putative peptidoglycan-associated protein (lmo2085 gene) and putative UDP-glucose phosphorylase (lmo1078 gene) as osmotic stress proteins (Burgess et al., 2016).

The main mechanism of the osmotic stress response in L. monocytogenes involves osmoprotectants. In their absence, Ctc protein provides protection. The contribution of the remaining proteins presented is not fully understood. Food manufacturers should pay attention to the rightness of using salt as a preservative in the elimination of microorganisms from food, especially L. monocytogenes, due to the advanced mechanisms of adaptation to high salt concentration.

In recent years, there has been a demand for low-salt products, which forces searching for new technologies to control microbiological hazards in low-salt products. The currently 


\section{Adaptative expression regulatrors $\longrightarrow \sigma^{\mathrm{B}}, \sigma^{\mathrm{L}}, \mathrm{CtsR} \longrightarrow$ Production/activation of stress proteins}

- $\mathrm{ClpP}, \mathrm{ClpC}, \mathrm{HtrA}$

- CspD, Hf, Ctc

- ProA, ProB, LMO1078

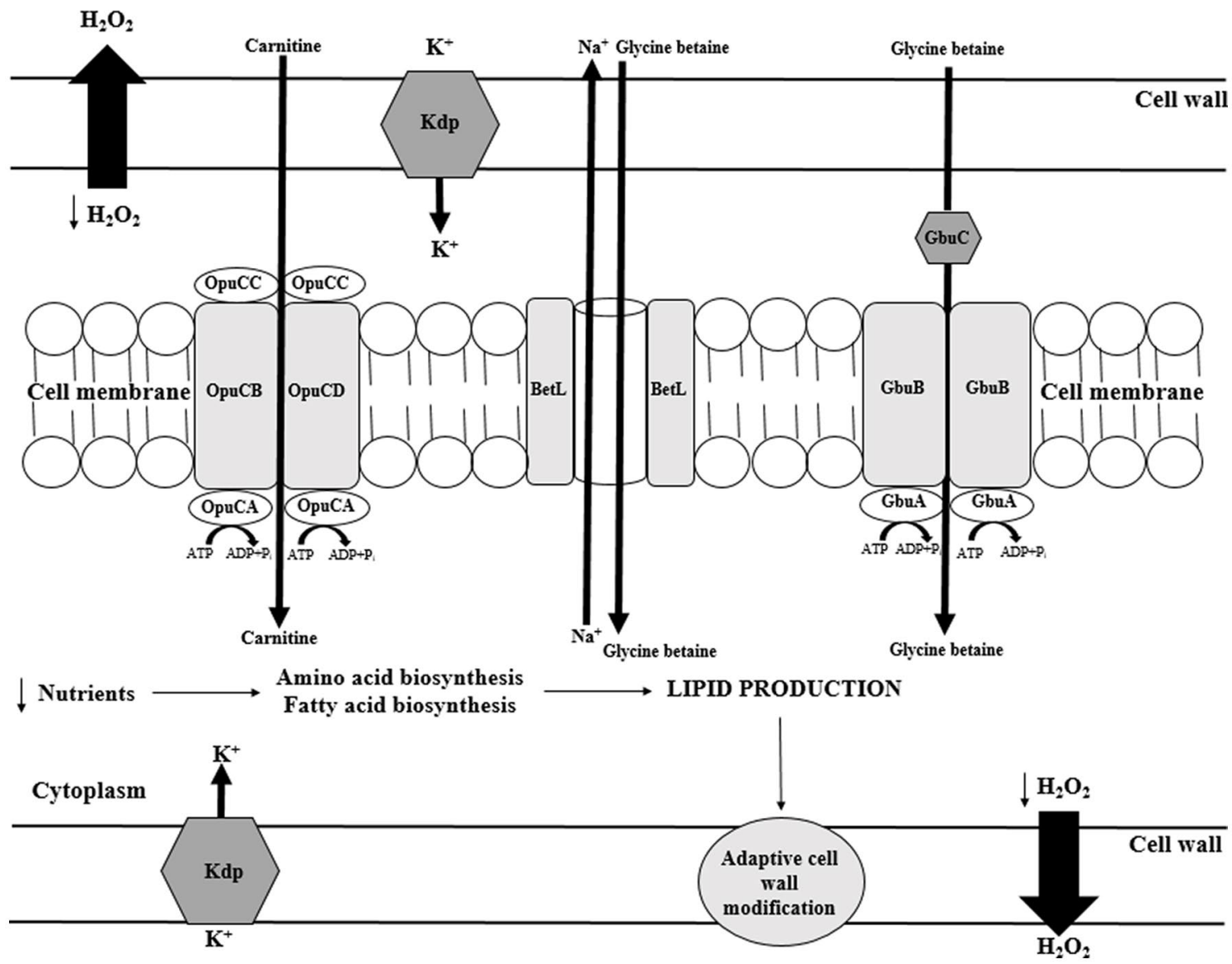

FIGURE 3 | Transport of compatible solutes in response to osmotic stress in L. monocytogenes (CtsR - negative transcription regulator; ClpP, ClpC - ATPdependent Clp protease; HtrA - serine protease; Csp - cold shock proteins; Hfq - the RNA binding protein; Ctc - 50S ribosomal protein L25; ProBA - proline synthesis enzyme system; Kdp - operon response regulator; Gbu - glycine betaine; OpuC - ATP-dependent carnitine transporter; ATP - adenosine triphosphate; ADP - Adenosine 5'-diphosphate; and BetL - glycine betaine transporter).

used alternative to salt (especially in meat products) is the treatment with high isostatic pressures, activated plasma, pulsed UV light, or active packaging (Fraqueza et al., 2021). In our opinion, an attractive solution would be natural substances with antimicrobial activity (e.g., essential oils and plant extracts).

\section{Temperature}

Another factor ensuring food safety is temperature, both high and low. Heat treatment (pasteurization and sterilization) is one of the most common methods of assuring food safety and microbial elimination. However, too low temperature of such a process might not effectively eliminate the pathogen, and too high temperature may affect the organoleptic properties of food. In turn, low temperatures (e.g., cold stores) aim to limit the growth of undesirable microorganisms in food.
Listeria monocytogenes is able to survive and grow in a wide temperature range, i.e., $0-45^{\circ} \mathrm{C}$ (Arioli et al., 2019). Depending on the physiological state of the cell, inactivation of L. monocytogenes ranges from $10 \mathrm{~min}$ to $12 \mathrm{~s}$ at $55-65^{\circ} \mathrm{C}$ (Smelt and Brul, 2014).

Reaction to elevated temperature is associated with increased expression of heat shock proteins (Hsp). Hsp stabilize proteins and prevent improper folding and aggregation of proteins (Figure 4). In response to heat stress, L. monocytogenes increase the production of these proteins, thereby stimulating the repair of thermally denatured proteins. Listeria monocytogenes possess III classes of heat shock-associated genes. Genes of class I ( $g r o E$, dnaK, dnaJ, groEL, and groES) are overexpressed during the accumulation of denatured proteins in the cytosol and act as intracellular chaperones. 

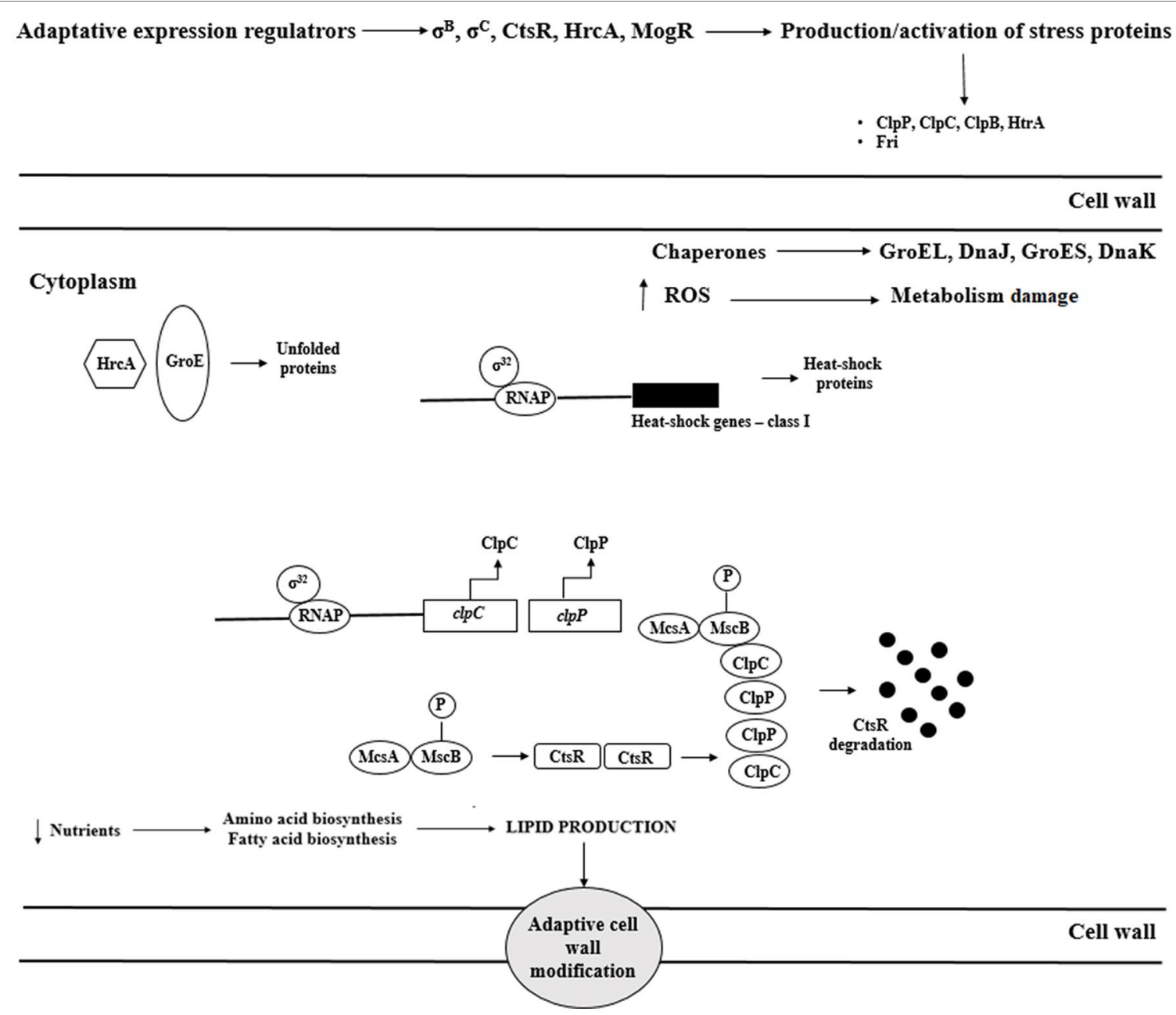

FIGURE 4 | Regulation of heat shock response of L. monocytogenes (ROS - reactive oxygen species; Msc - tyrosine kinase; McsA - zinger finger protein; HtrA serine protease; ClpC - ATP-dependent Clp protease; HrcA - Heat-inducible transcription repressor; CtsR - negative transcription regulator; Fri - ferritin-like protein; and RNAP - RNA polymerase enzyme).

Class III genes encode ATP-dependent proteins of caseinolytic activity (ClpB, ClpC, ClpP, and ClpE; Bucur et al., 2018). These proteins cooperate to maintain the proper protein structure at high temperatures. The proteins GroEL and GroES (regulation of basic cellular processes) and DnaK, and DnaJ (stabilization of the conformation of unfolded proteins) are the main chaperones protecting L. monocytogenes against heat stress. Also, ClpE and $\mathrm{ClpC}$ (caseinolytic activity) are indispensable during the replication at elevated temperatures and nutrients deficiency. During heat stress, these proteins participate in the regulation of proteolysis and proper protein folding. Genes of class I and III are negatively regulated by HrcA and CtsR, respectively, whereas class II genes are under positive control of $\sigma^{\mathrm{B}}$ (Nair et al., 2000). GroE regulates HrcA activity. Under optimal growth conditions, the interaction of HrcA with GroE inhibits transcription of class I genes. At elevated temperature, unfolded proteins bind GroE contributing to HrcA inactivation and enabling binding of RNA-s32 polymerase with promoters and gene expression.
At $37^{\circ} \mathrm{C}$, CtsR is stabilized by McsA, which results in class III gene repression. At increased temperature, McsB modifies CtsR conformation preventing its binding with gene promoters. As a result, RNA-s32 polymerase binds with promoters leading to gene expression, and CtsR is degraded (Figure 4; Kocaman and Sarimehmetoğlu, 2016). ClpC expression is negatively controlled at the transcription level, either directly or indirectly, by PrfA (Ripio et al., 1998).

Heat shock proteins, i.e., DnaK, ClpC ATPase, ClpP serine prosthesis, and Ctc protein also participate in the osmotic stress response. Thus, proteins involved in the reaction to osmotic and heat stress interact with each other (Figure 5).

During food processing, microbes experience low temperatures. Cold stress response in bacteria is three-step, i.e., cold shock, acclimatization, and adaptation (Kocaman and Sarimehmetoğlu, 2016). At $10^{\circ} \mathrm{C}$, amino-acid starvation, oxidative stress, synthesis of misfolded proteins, reconstruction of a cell wall, changes of metabolism, and induction of global regulatory reactions occur (Lianou and Sofos, 2007). A fast decrease below 


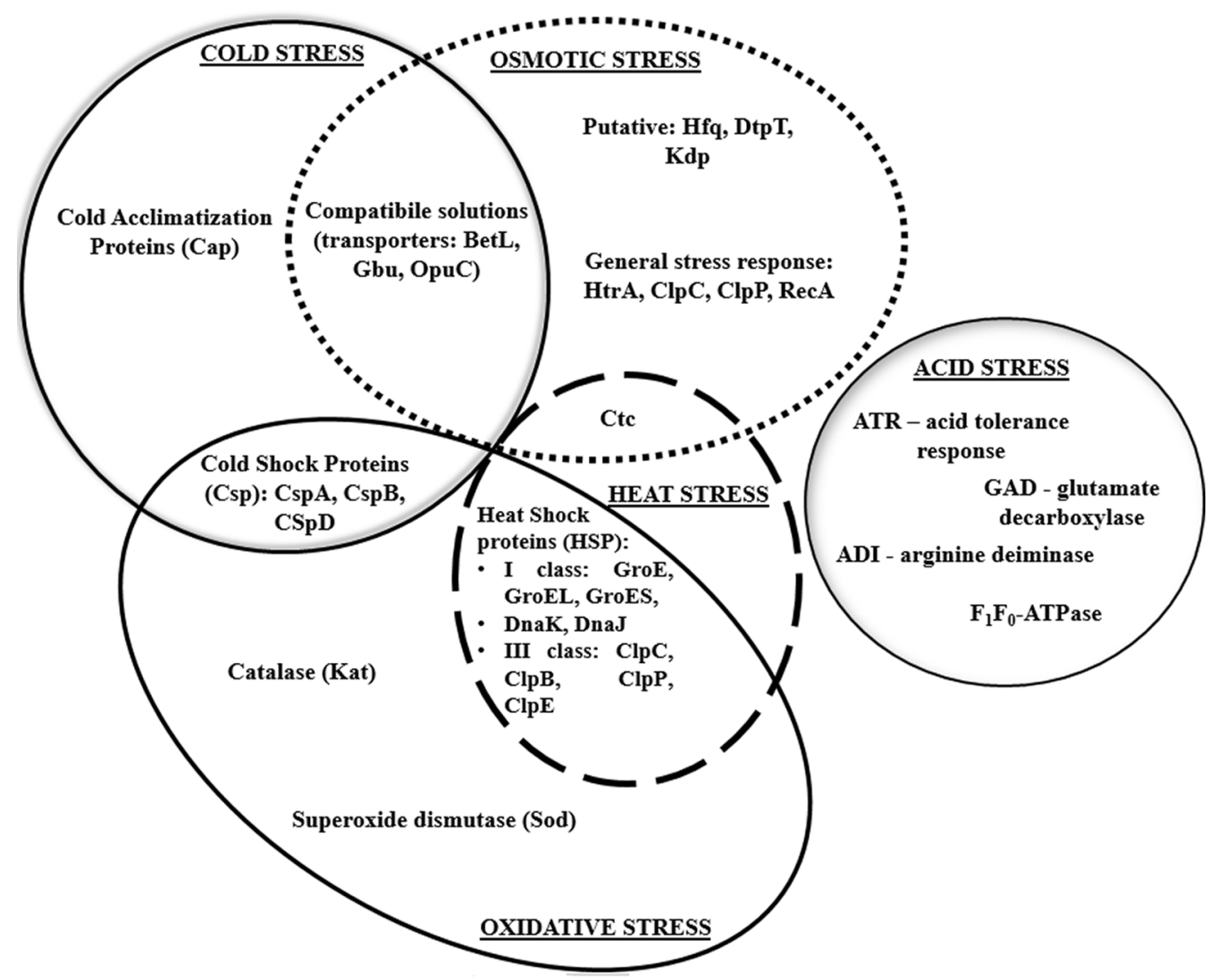

FIGURE 5 | Interaction of various stress response mechanisms in L. monocytogenes.

optimal temperature, termed cold shock, triggers the synthesis of cold shock proteins (Csp). Csp are small proteins (65-70 aa) of highly conserved structure, expressed at a low level at optimal temperature $\left(37^{\circ} \mathrm{C}\right.$; Schmid et al., 2009). Csp function as a molecular chaperone, enabling replication, transcription, and translation at low temperatures (Lee et al., 2012). Csps bind to a single-stranded nucleic acid via ribonucleoprotein binding motifs RNP1 and RNP2, thereby stabilizing nucleic acid conformation and preventing its degradation (Barria et al., 2013). CspA, CspB, and CspD contribute to adaptation to a varying extent (Schmid et al., 2009). Schmid et al. (2009) have shown that L. monocytogenes $\Delta \mathrm{cspA}$ and $\Delta \mathrm{cspD}$ mutants significantly worse responded to cold stress. Stress conditions also induce cold acclimatization proteins (Cap; Figure 6; Barria et al., 2013). The main mechanism of response to cold stress in L. monocytogenes relies on the action of both, Csp and Cap proteins. There are also other mechanisms involved in the cold stress response, supporting Csp and Cap action. Another cold stress response mechanism involves osmolytes and cryoprotectants (Angelidis and Smith, 2003). A key role as a cryoprotectant is attributed to branched-chain fatty acids of the cell membrane, ensuring membrane integrity at low temperatures (Becker et al., 2000). During cold shock, $\sigma^{\mathrm{B}}$ confers growth phase-dependent adaptation and assures efficient accumulation of cryoprotectants such as betaine and carnitine.
Eight Rsb proteins modulate $\sigma^{\mathrm{B}}$ binding to the primary regulator through protein-protein interaction and phosphates transfer (Liu et al., 2019).

High temperature is a frequently used factor for the elimination of microorganisms in the food industry. To prevent loss of organoleptic properties, producers shorten the thermal processing of food. Unfortunately, such an approach may generate sub-lethal stress leading to the resistance acquisition in microorganisms. Listeria monocytogenes has developed several adaptation mechanisms to both high and low temperatures. Therefore, food producers should consider combining the thermal treatment with other methods, e.g., chemicals or natural preservatives (e.g., bacteriocins). The combination of methods can provide a lethal effect on microorganisms (safety for the consumer) without affecting the properties of the food.

\section{$\mathrm{pH}$}

Acid stress is one of the most common stresses faced by foodborne pathogens. Low $\mathrm{pH}$ increases $\mathrm{H}^{+}$concentration, decreasing an internal $\mathrm{pH}(\mathrm{pHi})$ and inhibiting microbial growth. The ability to withstand acid stress determines bacterial survival in acid food products (Ryan et al., 2008). Bacteria need to restore homeostasis inside the cell via a passive mechanism (an increase of cytoplasm buffer capacity) or an active one (using a proton pump) to survive (Ryan et al., 2008). In food processing 

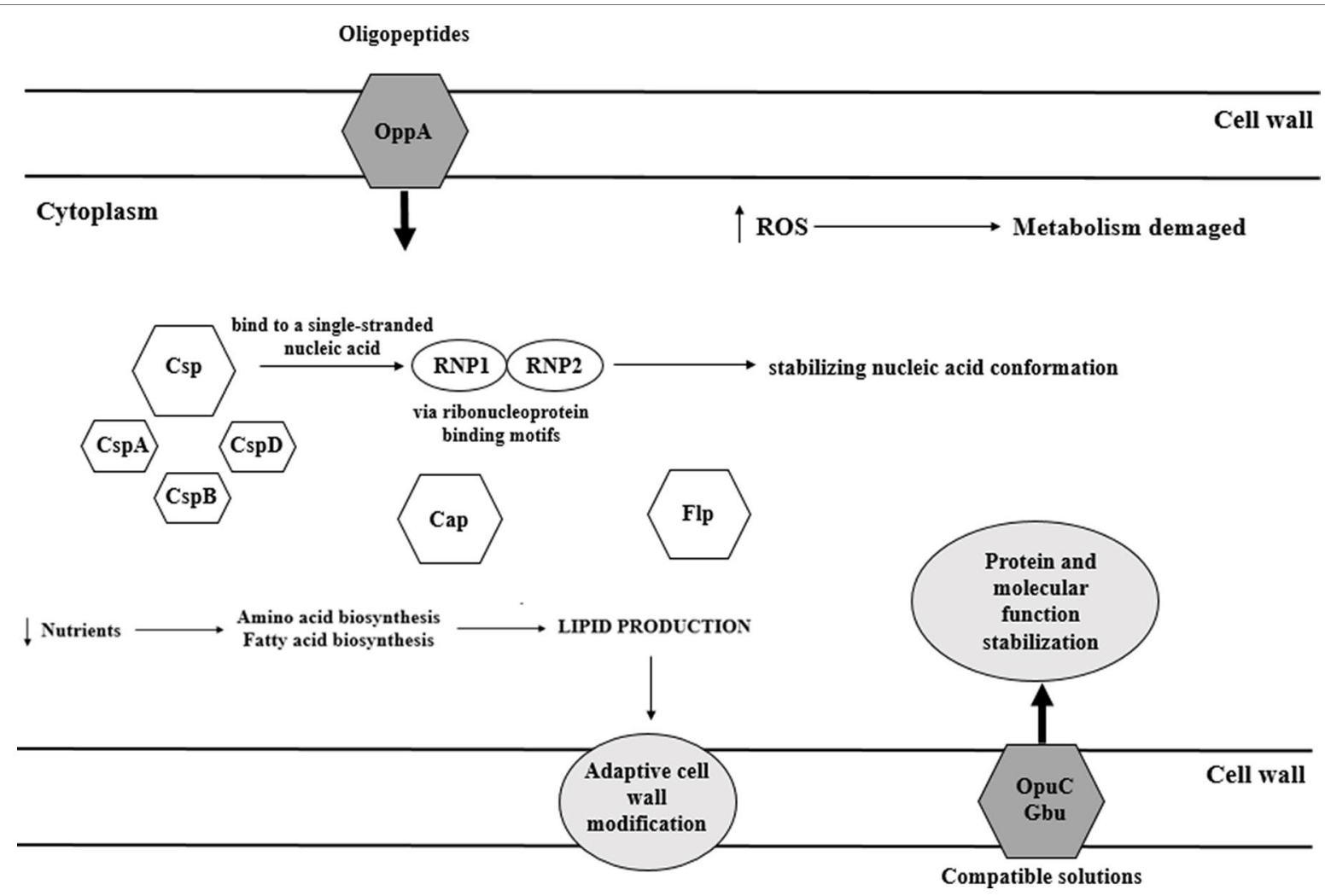

FIGURE 6 | Cold stress response of L. monocytogenes (OpuC - ATP-dependent carnitine transporter; Gbu - glycine betaine; ROS - reactive oxygen species; Csp cold-shock protein; Cap - cold acclimatization protein; and Flp - ferritin-like proteins).

plants, L. monocytogenes is exposed to many acids (benzoic, salicylic, lactic, and propionic acid), commonly used as food preservatives and disinfectants. Other acid challenges, i.e., gastric juice and bile salts, the pathogen encounters in the human food tract (Begley et al., 2002).

There are four potential mechanisms responsible for the homeostasis maintenance in L. monocytogenes, i.e., acid tolerance response (ATR), glutamate decarboxylase (GAD), arginine deiminase (ADI), and $\mathrm{F}_{1} \mathrm{~F}_{0}$-ATPase (Cotter et al., 2005). The major role of ATR mechanism is the cell protection against the lethal effect of stress following short exposure to mild acids (Koutsoumanis et al., 2003). The GAD system affects survival in food products of low $\mathrm{pH}$ (juices, yogurts, salads, and mayonnaise). The GAD system compromises five genes. Three genes ( $g a d D 1$, gadD2, and $g a d D 3)$ encode decarboxylases and two genes encode ( $\mathrm{gadT1}, \operatorname{gadT2}$ ) antiporters (Melo et al., 2015). The GAD system converts extracellular glutamate to $\gamma$-aminobutyrate acid (GABA), elevating pHi (Werbrouck et al., 2009). Subsequently, GABA is exchanged for glutamate at the cell membrane by GadT2 antiporter. As a consequence, an intracellular proton is consumed, contributing to alkalization of the environment and $\mathrm{pH}$ homeostasis. Researchers have shown that strains with low GAD activity are susceptible to gastric juice (Ryan et al., 2009). Extremely acid pH activates another system: the ADI pathway (Soares and Knuckley, 2016). ADI converts, imported from the external environment, arginine to ornithine, $\mathrm{CO}_{2}$, ammonia, and ATP. Three enzymes participate in the arginine conversion, i.e., ADI, carbamoyltransferase, and carbamate kinase, encoded by $\operatorname{arc} A, \operatorname{arc} B$, and $\operatorname{arc} C$, respectively. Ornithine is then transported from the cell, in an energyindependent manner, via membrane-bound antiporter, encoded by $\operatorname{arc} D$ gene. In turn, ammonia, produced as a by-product, reacts with intracellular protons generating $\mathrm{NH}_{4}^{+}$, thereby increasing cytoplasmic $\mathrm{pH}$ and protecting the cell from the acid environment (Figure 7; Matereke and Okoh, 2020). ATP produced during arginine conversion may be used by $\mathrm{F}_{1} \mathrm{~F}_{0^{-}}$ ATPase. This multisubunit enzyme generates a proton gradient, enabling $\mathrm{H}^{+}$expulsion and homeostasis restoration (Ryan et al., 2009). The enzyme consists of two distinct domains: the membrane domain $F_{0}$, which functions as a channel for protons translocation, and the cytoplasmic domain $\mathrm{F}_{1}$ catalyzing ATP synthesis and hydrolysis (Figure 7; Smith et al., 2013). The three discussed systems, i.e., ATR, GAD, and $\mathrm{F}_{1} \mathrm{~F}_{0}$-ATPase, act at the same time (Figure 5). Interactions between them ensure survival and adaptation to acid stress.

In the food production environment, L. monocytogenes may also face sublethal alkaline stress associated with the use of detergents and disinfectants. The adaptation to such conditions involves increased production of acids and induction of transporters and enzymes responsible for protons retention and cell surface modifications (Soni et al., 2011). Usually, in response to high $\mathrm{pH}$, the general stress proteins production, 


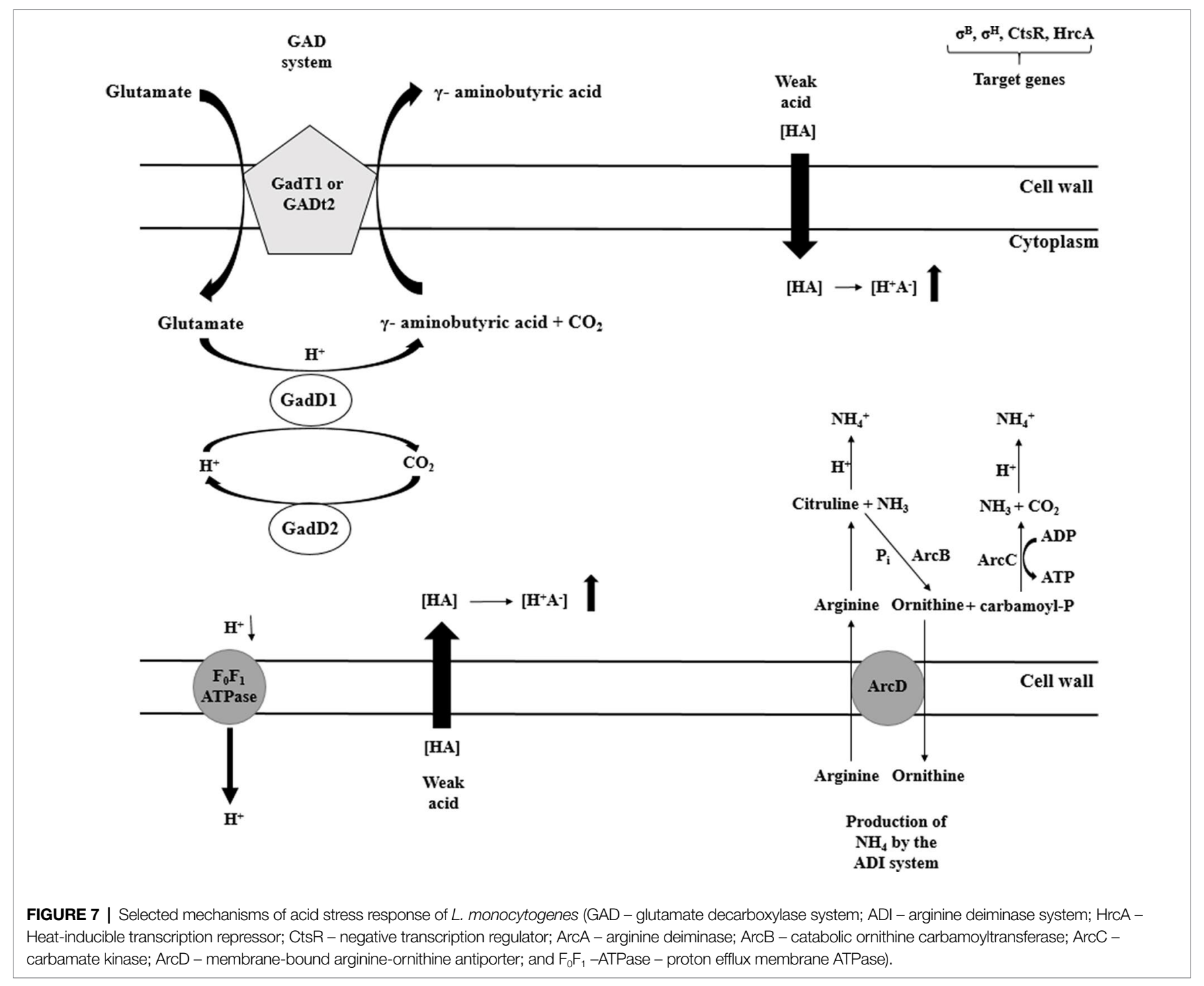

ATP generation (via ATP synthase conjugation with $\mathrm{H}^{+}$), and increased expression and activity of the monovalent cation/ proton antiporters are observed (Giotis et al., 2010).

Many foodborne pathogens, including L. monocytogenes, develop adaptation to low $\mathrm{pH}$ and cross-resistance to other stresses upon exposure to acid stress. This cross-protection phenomenon may have severe consequences for food safety, as L. monocytogenes can survive various treatments, such as heat stress, cold stress, and osmotic stress. It is necessary to search for new disinfection methods in the food industry, limiting acids and alkalis use. An attractive solution could be substances of natural origin (herbs extracts and essential oils) or bacteriocins (environmentally friendly and safe for the consumer). Lately, increasing attention is being paid to essential oils as natural additives to extend the shelf life of food products (Tongnuanchan and Benjakul, 2014). Work (Shan et al., 2009; Efenberger-Szmechtyk et al., 2021) on natural preservatives is ongoing, and the results are promising. It is also necessary to understand the impact of such new applications on the survival of L. monocytogenes.

\section{Nutrients}

The availability of ingredients in the FPE varies. Availability is low in post-disinfection areas. In turn, during food processing, there may be different types of waste, such as blood, fruit juices, etc. The availability of nutrients influences microbial biofilm formation, undesirable in the food industry. Listeria monocytogenes is able to use various compounds in the form of carbon, and/or energy sources to thrive in potential niches also within the food industry (Tapia et al., 2020). Thus, L. monocytogenes can survive and multiply in a variety of environments with different availability of nutrients. The pathogen possesses transport systems for various sugars allowing adaption to changing environmental conditions.

The genome of $L$. monocytogenes contains a significant number of ABC transporters phosphoenolpyruvate: sugar phosphotransferase (PTS) systems, most of which have not yet been fully characterized (Stoll and Goebel, 2010; Deutscher et al., 2014). Additionally, L. monocytogenes can utilize many carbon sources to produce biofilms on food processing 
surfaces (Tapia et al., 2020). In laboratory conditions, L. monocytogenes can grow in commonly used bacteriological media. Increased growth rates occur in the presence of fermentable sugars. However, nutritional requirements of L. monocytogenes are strain-dependent and reflect the ability of the pathogen to survive in a wide range of environmental conditions (Lungu et al., 2009). Premaratne et al. (1991) have shown that L. monocytogenes requires glucose, glutamine, leucine, isoleucine, arginine, methionine, valine, cysteine, riboflavin, biotin, and thiamine for growth. On the other hand, fructose, mannose, cellobiose, trehalose, maltose, glycerol, glucosamine, and $\mathrm{N}$-acetylglucosamine support its growth in the absence of glucose. Tapia et al. (2020) have observed that the utilization of lactose by $L$. monocytogenes triggers a strong $\sigma^{\mathrm{B}}$-dependent stress response, which may have implications for L. monocytogenes in the food chain. Tapia et al. (2020) have demonstrated the potential role of lactose in the activation of the $\sigma^{\mathrm{B}}$-dependent stress response, which may have implications for L. monocytogenes in the food chain. They have observed that the pathogen in the presence of lactose, compared to other carbon sources tested, increased virulence, biofilm production potential, and resistance to heat and acids (Tapia et al., 2020). Thus, L. monocytogenes ability to utilize lactose may increase its survival in food processing (dairy), resulting in a higher risk of reinfection. Collectively, the ability to use alternative energy sources, e.g., carbohydrate polymers, proteins, nucleic acids, and lipids, determines the survival and growth of the pathogen in the human gastrointestinal tract (Lungu et al., 2009).

Zhou et al. (2012) have found that limited access to nutrients increased the biofilm formation ability of L. monocytogenes. Also, the presence of food by-products (meat juice, pork serum, or fat) in the processing environment stimulated biofilm formation (Van Houdt and Michiels, 2010). Listeria monocytogenes in the biofilm are resistant to disinfection methods. Therefore, efficient cleaning and disinfection procedures are of great importance.

\section{Reactive Oxygen Species}

Disinfectants, commonly used in the food industry, trigger in bacteria oxidative stress. Reactive oxygen species (ROS), such as hydrogen peroxide or hydroxyl radicals, can be produced as by-products of metabolism or during reduction of the respiratory chain or other stress factors (Bowman et al., 2010; Burgess et al., 2016). In order to withstand exposure to oxidizing agents, e.g., sodium hypochlorite, cells must activate mechanisms to repair damages of proteins, the cytoplasmic membrane, and nucleic acids. Listeria monocytogenes under oxidative stress activates a survival strategy that includes the expression of $\operatorname{sig} B$, cold and heat shock proteins, proteases (ClpC, ClpP, and GroEL), and ROS detoxification systems (Manso et al., 2020). ROS detoxification systems include superoxide dismutase (Sod), catalase (Kat), and alkylhydroperoxidase (AhpCF; Bucur et al., 2018). Strains without Kat and Sod activity showed increased sensitivity to oxidative stress and were low virulent (Archambaud et al., 2006; Azizoglu and Kathariou, 2010). Also, ferritin plays an essential role in the oxidative stress response of L. monocytogenes (Dussurget et al., 2005). Rea et al. (2005) have reported that L. monocytogenes
$\Delta$ perR mutants (peroxide regulon repressor) displayed elevated sensitivity to hydrogen peroxide and limited growth.

Manso et al. (2020) have shown that oxidative stress is temperature-dependent. The lower temperature increased oxidative stress response. Both stressful conditions caused similar damage to nucleic acids and cell membranes (Manso et al., 2020). Most of the disinfectants used in the food industry are applied at low temperatures, favoring the acquisition of resistance by L. monocytogenes. Therefore, food manufacturers should consider the type of active substances in disinfectants and the disinfection process temperature.

\section{Disinfectants}

One method to maintain food and consumer safety is the use of appropriate cleaning and disinfection procedures. Chemical preparations are most common. An important problem is the acquisition of resistance to disinfectants by L. monocytogenes due to the residues of chemical substances in sub-lethal concentrations after disinfection. The most commonly used disinfectants for L. monocytogenes are quaternary ammonium compounds (QACs) and chlorine-based biocides (Minarovicova et al., 2018; Aryal and Muriana, 2019). Listeria monocytogenes strains resistant to disinfectants contribute to sporadic cases as well as outbreaks of listeriosis. The antimicrobial effectiveness of biocides may be affected by the presence of organic pollutants. Also, the biofilm structure protects L. monocytogenes against the action of disinfectants (Duze et al., 2021). The main cause of resistance of $L$. monocytogenes to antimicrobial agents is horizontal gene transfer (HGT) of mobile genetic elements such as plasmids and transposons carrying resistant genes. Another mechanism relies on the activation of efflux pump systems. To date, six genes ( $m d r L$, lde, cassette $b c r A B C, q a c H$, emrE, and emrC), located on mobile genetic elements, related to the efflux system, have been identified in $L$. monocytogenes in response to disinfectants action. Table 3 presents genes conferring biocide tolerance. Two major efflux pump genes, $m d r L$ and $l d e$, are present in nearly all L. monocytogenes serotypes (Haubert et al., 2019). The MDRL pump detoxifies macrolide, cefotaxime, heavy metals, and ethidium bromide (EtBr). In turn, the Lde pump detoxifies fluoroquinolones, antibiotics, and intercalating dyes such as EtBr and acridine orange (Mata et al., 2000). Jiang et al. (2019) confirmed the role of MdrL in disinfectants tolerance in L. monocytogenes (in the survival of biocidal stress in food). Other efflux pump genes responsible for the increased tolerance to QAC are emrE and emrC genes, located on the LGI1 genomic mobile island and pLMST6 plasmid, respectively (Kovacevic et al., 2016; Kremer et al., 2017). Kropac et al. (2019) showed that plasmid pLMST6 increased tolerance only to QAC-based disinfectants. However, as plasmids aid L. monocytogenes to survive in FPE, they may help in biocide tolerance. Kremer et al. (2017) have shown a link between isolates with plasmid pLMST6, pump efflux, emrC gene, and reduced antibiotic susceptibility. In turn, Noll et al. (2020) have studied the impact of adaptation L. monocytogenes against antimicrobials. Listeria monocytogenes cells after exposure to benzalkonium chloride showed a 2-fold increase in MIC compared to the disinfectant 
TABLE 3 | Genes involved in biocide tolerance in L. monocytogenes.

\begin{tabular}{|c|c|c|c|}
\hline The source of the isolation L. monocytogenes & Biocide and exposure time & $\begin{array}{l}\text { Presence/ } \\
\text { expression of genes }\end{array}$ & Reference \\
\hline $\begin{array}{l}\text { L. monocytogenes } 08-5,578 \text { [clinical strain responsible for the } \\
\text { Canadian deli meat listeriosis outbreak (2008)] }\end{array}$ & Benzalkonium chloride - $16 \mathrm{~h}$ & emrELm & Kovacevic et al., 2016 \\
\hline Isolates from product contact and non-product contact surfaces & Benzalkonium chloride $-24 \mathrm{~h}$ & Transposon Tn6188 & Ortiz et al., 2016 \\
\hline $\begin{array}{l}\text { L. monocytogenes H7550 (strain implicated in the 1998-1999 } \\
\text { multistate outbreak involving contaminated hot dogs) }\end{array}$ & Benzalkonium chloride - $48 \mathrm{~h}$ & bcrABC & Elhanafi et al., 2010 \\
\hline Isolates from nine Norwegian meat- and salmon processing plants & Benzalkonium chloride $-48 \mathrm{~h}$ & bcrABC & Møretrø et al., 2017 \\
\hline L. monocytogenes strains from Switzerland and Finland & Benzalkonium chloride - $48 \mathrm{~h}$ & bcrABC, emrE & Meier et al., 2017 \\
\hline Isolates from food and food processing plants & Benzalkonium chloride -7 days & $m d r L$ & Yu et al., 2018 \\
\hline Isolates from foods and food processing plants & $\begin{array}{l}\text { Benzalkonium chloride, Cadmium } \\
\& \text { arsenic }-48 \mathrm{~h}\end{array}$ & CadA 1, CadA2 & Ratani et al., 2012 \\
\hline $\begin{array}{l}\text { Isolates from food and food-processing environments in southern } \\
\text { Brazil }\end{array}$ & $\begin{array}{l}\text { Benzalkonium chloride \& Cadmium } \\
\text { chloride }-48 \mathrm{~h}\end{array}$ & mdrL, lde & Haubert et al., 2019 \\
\hline Isolates from a dairy cattle farm & $\begin{array}{l}\text { Benzalkonium chloride, Virkon, } \mathrm{H}_{2} \mathrm{O}_{2} \\
\text { and sodium Hypochlorite }-12-48 \mathrm{~h}\end{array}$ & qacED1 & Mohammed et al., 2017 \\
\hline Isolates from food production facilities & $\begin{array}{l}\text { Benzalkonium chloride and Cetylpyridinium } \\
\text { chloride }-72 \mathrm{~h}\end{array}$ & Pdu, Cob-cbi, and Eut & Fox et al., 2011 \\
\hline
\end{tabular}

treatment and reduced sensitivity to antibiotics (ceftriaxone, gentamicin, linezolid, tetracycline, and a combination of trimethoprim and sulfamethoxazole). The tolerance to disinfectants does not always induce cross-resistance to antibiotics. Roedel et al. (2019) have revealed that tolerance to biocides did not induce AMR. Antibiotic resistance in L. monocytogenes may severely influence public health due to poor treatment outcomes and sequelae treatment failure. The frequent use of disinfectants in the food processing industry can lead to selective pressure and promote the absorption of plasmides, e.g., containing brcABC from other L. monocytogenes strains (Hingston et al., 2019).

It is relevant to control the used disinfectants to ensure the effective elimination of microorganisms from the food industry. In our opinion, periodical change of the active substances would have a beneficial impact. Such an action would limit the acquisition of resistance traits among microorganisms. Food manufacturers should monitor the effectiveness of agents and avoid extensive storage of open packages of disinfectants.

\section{Bacteriocins}

Researchers have been constantly searching for new methods allowing microbes elimination from the FPE. These methods should be cheap, environmentally friendly, and, above all, safe for consumers. One alternative is the use of bacteriocins. Bacteriocins are antimicrobial peptides produced extensively by lactic acid bacteria. These molecules are mainly active against Gram-positive bacteria, including L. monocytogenes (Chikindas et al., 2018). Bacteriocins are natural and safe food preservatives (Silva et al., 2018). Nisin is the class I bacteriocin, approved as a food preservative. Listeria monocytogenes resistance to nisin is associated with changes in the cytoplasmic membrane. Ming and Daeschel (1993) have demonstrated an increased proportion of straight-chain fatty acids and a decreased branched-chain fatty acids ratio. In turn,
Wu et al. (2018) have reported that L. monocytogenes bacilli exposed to a high nisin concentration had lowered expression of genes $d l t A$ and $d l t B$, indicating that $\mathrm{D}$-alanine residue is not linked to bacteriocin resistance. Scientists emphasized the role of regulation of the expression of two cell wall synthesis-associated genes: $\operatorname{lmo} 2714$ (membrane-anchored peptidoglycan protein) and lmo2522 (for cell wall-binding protein with possible effects on nisin tolerance; $\mathrm{Wu}$ et al., 2018). Other genes/operons that affect nisin resistance include lmo2229 (Collins et al., 2012), telA (Collins et al., 2010a), mprF (Thedieck et al., 2006), anrAB (Collins et al., 2010b), and dltABCD (Abachin et al., 2002). Many class II bacteriocins with antilisterial activity, including pediocin, sacacin $\mathrm{P}$, leukocin, enterococin, creaticine Y105, garvicin, and linocin M18 have been also isolated and characterized (Ríos Colombo et al., 2018). Natural resistance of L. monocytogenes ranges from 1 to $8 \%$, depending on bacteriocin and tested strain (Macwana and Muriana, 2012).

Listeria monocytogenes response to bacteriocins involves different mechanisms, i.e., changes in cell structures and the participation of relevant proteins which work together.

\section{STRESS ADAPTATION}

Listeria monocytogenes can regulate and fine-tune gene expression to adapt to diverse stress conditions encountered during foodborne transmission (Orsi et al., 2021). The mechanism allowing L. monocytogenes to respond to stress conditions is the cross-talk between $\sigma^{\mathrm{B}}$ and PrfA.

Application of sublethal doses of stress factors in the FPE may increase AMR or stimulate the resistance to other stress conditions (cross-resistance) and higher doses of the same stress (stress adaptation; Faezi-Ghasemi and Kazemi 2015). Two-component signal transduction systems (TCS) enable bacteria to detect and adapt to a variety of stressors. The prototype modular TCS consists 
of a periplasmic sensor histidine kinase (HK) and a cognate cytoplasmic response regulator (RR; Gao and Stock, 2009). The action of TCS relies on the phosphorylation of proteins. In a direct phosphotransfer system, the HK sensor domain detects the stimulus leading to ATP-dependent autophosphorylation at a specific histidine (His) residue catalyzed by the kinase domain. Cognate RR then catalyzes the transfer of a phosphoryl group to its own aspartate (Asp) residue in the regulatory domain. Phosphorylation of the RR regulatory domain leads to activation of the effector domain and ultimately to an appropriate response to a specific stimulus (Casino et al., 2010).

Mobile genetic elements play a crucial role in the environmental adaptation and stability of L. monocytogenes. Such elements are common among L. monocytogenes isolates from FPEs (Hurley et al., 2019) and may contain genes mediating tolerance to heat shock (Pöntinen et al., 2017), salt and acid stress (Hingston et al., 2019; Naditz et al., 2019), and biocides (Meier et al., 2017). Also, plasmids are relevant for rapid adaptation to changing environmental conditions. The frequency of plasmids in L. monocytogenes is up to $79 \%$ (Elhanafi et al., 2010). The majority of data concerns plasmids containing genes conditioning resistance to disinfectants (Elhanafi et al., 2010; Rakic-Martinez et al., 2011), heavy metals (Rakic-Martinez et al., 2011), increased acid tolerance, and sensitivity to cold (Hingston et al., 2017), reduced tolerance to salt stress (Zhang et al., 2018), and antibiotics (Hadorn et al., 1993). Plasmids were more frequently isolated from food strains than from clinical strains (McLauchlin et al., 1997; Hingston et al., 2019). More, plasmids were more common among recurrent $L$. monocytogenes strains (75\%) than among sporadic strains (35\%) isolated from food or food processing plants (Harvey and Gilmour, 2001). These observations suggest that genes found in L. monocytogenes plasmids may be helpful for the pathogen's survival in such environments (Hingston et al., 2019). A phenomenon found in the food industry is also HGT. The phenomenon is responsible for features critical to the evolution, such as antibiotic resistance or increased virulence. HGT ensures increased survival of L. monocytogenes strains exposed to stress factors related to FPE, which prevents their elimination, especially in places that are difficult to clean (Palma et al., 2020).

\section{CROSS-RESISTANCE}

Cross-resistance is an essential aspect in the food industry, which often applies many stressors to assure food safety and food quality (Bergholz et al., 2012). Bergholz et al. (2012) have found that pre-exposure to osmotic stress enabled bacterial growth at low temperatures, whereas cold shock-induced crossprotection against salt stress. More, L. monocytogenes subjected to acidic conditions displayed increased resistance to $\mathrm{H}_{2} \mathrm{O}_{2}$, heat shock, ethanol, and oxidative and osmotic stress (Lou and Yousef, 1997; Ferreira et al., 2003). Adaptation to acid conditions may also increase L. monocytogenes resistance to nisin. Since the sublethal concentration of acids is frequently applied during food processing, cross-resistance of the acidadapted cell is of great importance (Mastronicolis et al., 2010).
Alonso-Hermando et al. (2009) have revealed that sodium hypochlorite induced AMR of L. monocytogenes. In turn, Faezi-Ghasemi and Kazemi (2015) have demonstrated increased susceptibility of L. monocytogenes to penicillin, ampicillin, gentamycin, tetracycline, trimethoprim/sulfamethoxazol, and rifampicin after stress exposure $[7 \% \mathrm{NaCl}, \mathrm{pH}=5.0$, and ethanol $(5 \% \mathrm{w} / \mathrm{v})]$. The researchers claimed that an acid environment leads to an influx of protons and anions to the cell cytoplasm, disturbing its metabolic functions and inducing the damage of proteins, nucleic acids, and cell membranes (Faezi-Ghasemi and Kazemi 2015). The knowledge of the crossresistance phenomenon may help in the appropriate designing of food processes, limiting the risk for public health.

\section{CONCLUSION}

In the presented review, we summarize the current knowledge about the adaptation of L. monocytogenes to stress factors in food processing plants. Although we know a lot about the stress response of $L$. monocytogenes, the pathogen is still present in the FPE and is a threat to the consumer. Mobile genetic elements determine the acquisition of new resistance traits to physical and chemical disinfection methods among L. monocytogenes strains. Food producers should not underestimate the risk of microorganisms present in the processing environment, especially L. monocytogenes. Therefore, high sanitary regimes and food processing control are indispensable for the reduction of foodborne listeriosis. Understanding the mechanisms of adaptation to environmental stress would significantly develop new, efficient, and cost-effective methods of controlling L. monocytogenes in the food industry. The knowledge of L. monocytogenes biology and constant control of the pathogen in FPE are critical to ensure food production safety.

\section{AUTHOR CONTRIBUTIONS}

NW-K and KS: conceptualization and project administration. KG-B and EW-Z: formal analysis. NW-K and JK: writing - original draft preparation and visualization. KS, KG-B, and EW-Z: writing review and editing. KS and EG-K: supervision. All authors contributed to the article and approved the submitted version.

\section{FUNDING}

The article is financed with a fund from the contest for doctoral students under the "Excellence Initiative Research University" program in Nicolaus Copernicus University in Torun.

\section{ACKNOWLEDGMENTS}

This review was created during the research work carried out as part of a grant for participants of doctoral studies at the Faculty of Pharmacy of Collegium Medicum in Bydgoszcz (no. MN-SDF-4/WF/2019). 


\section{REFERENCES}

Abachin, E., Poyart, C., Pellegrini, E., Milohanic, E., Fiedler, F., Berche, P., et al. (2002). Formation of D-alanyl-lipoteichoic acid is required for adhesion and virulence of Listeria monocytogenes. Mol. Microbiol. 43, 1-14. doi: 10.1046/j. 1365-2958.2002.02723.x

Alonso-Hermando, A., Capita, R., Prieto, M., and Alonso-Calleja, C. (2009). Adaptation and cross-adaptation of Listeria monocytogenes and Salmonella enterica to poultry decontaminations. J. Microbiol. 47, 142-146. doi: 10.1007/ s12275-008-0237-5

Angelidis, A. S., and Smith, G. M. (2003). Three transporters mediate uptake of glycine betaine and carnitine by Listeria monocytogenes in response to hyperosmotic stress. Appl. Environ. Microbiol. 69, 1013-1022. doi: 10.1128/ AEM.69.2.1013-1022.2003

Archambaud, C., Nahori, M. A., Pizarro-Cerda, J., Cossart, P., and Dussurget, O. (2006). Control of Listeria superoxide dismutase by phosphorylation. J. Biol. Chem. 281, 31812-31822. doi: 10.1074/jbc.M606249200

Arioli, S., Montanari, C., Magnani, M., Tabanelli, G., Patrignani, F., Lanciotti, R., et al. (2019). Modelling of Listeria monocytogenes Scott A after a mild heat treatment in the presence of thymol and carvacrol: effects on culturability and viability. J. Food Eng. 240, 73-82. doi: 10.1016/j.jfoodeng.2018.07.014

Aryal, M., and Muriana, P. M. (2019). Efficacy of commercial sanitizers used in food processing facilities for inactivation of Listeria monocytogenes, E. coli O157:H7, and Salmonella biofilms. Foods 8:639. doi: 10.3390/foods8120639

Azizoglu, R. O., and Kathariou, S. (2010). Temperature dependent requirement for catalase in aerobic growth of Listeria monocytogenes F2365. Appl. Environ. Microbiol. 76, 6998-7003. doi: 10.1128/AEM.01223-10

Barria, C., Malecki, M., and Arraiano, C. M. (2013). Bacterial adaptation to cold. Microbiology 159, 2437-2443. doi: 10.1099/mic.0.052209-0

Becker, L. A., Evans, S. N., Hutkins, R. W., and Benson, A. K. (2000). Role of $\sigma^{\mathrm{B}}$ in adaptation of Listeria monocytogenes to growth at low temperature. J. Bacteriol. 182, 7083-7087. doi: 10.1128/JB.182.24.7083-7087.2000

Beckers, H. J., Soentoro, P. S. S., and Delfgou-van Asch, E. H. M. (1987). The occurrence of Listeria monocytogenes in soft cheeses and raw milk and its resistance to heat. Int. J. Food Microbiol. 4, 249-256. doi: 10.1016/01681605(87)90041-9

Begley, M., Gahan, C. G., and Hill, C. (2002). Bile stress response in Listeria monocytogenes LO28: adaptation, cross-protection, and identification of genetic loci involved in bile resistance. Appl. Environ. Microbiol. 68, 6005-6012. doi: 10.1128/AEM.68.12.6005-6012.2002

Bergholz, T. M., Bowen, B., Wiedmann, M., and Boor, K. J. (2012). Listeria monocytogenes shows temperature-dependent and independent responses to salt stress, including responses that induce cross-protection against other stresses. Appl. Environ. Microbiol. 78, 2602-2612. doi: 10.1128/AEM.07658-11

Bille, J., Blanc, D. S., Schmid, H., Boubaker, K., Baumgartner, A., Siegrist, H. H., et al. (2006). Outbreak of human listeriosis associated with Tomme cheese in Northwest Switzerland, 2005. Euro Surveill. 11, 91-93.

Birk-Urovitz, E. (2011). The 2008 Canadian Listeriosis outbreak: a result of knowledge ignored. McMaster University Medical Journal 8, 65-67.

Bowman, J. P., Lee Chang, K. J., Pinfold, T., and Ross, T. (2010). Transcriptomic and phenotypic responses of Listeria monocytogenes strains possessing different growth efficiencies under acidic conditions. Appl. Environ. Microbiol. 76, 4836-4850. doi: 10.1128/AEM.00315-10

Bucur, F. I., Grigore-Gurgu, L., Crauwels, P., Riedel, C. U., and Nicolau, A. I. (2018). Resistance of Listeria monocytogenes to stress conditions encountered in food and food processing environments. Front. Microbiol. 9:2700. doi: $10.3389 /$ fmicb.2018.02700

Burall, L. S., Laksanalamai, P., and Datta, A. R. (2012). Listeria monocytogenes mutants with altered growth phenotypes at refrigeration temperature and high salt concentrations. Appl. Environ. Microbiol. 78, 1265-1272. doi: 10.1128/ AEM.06576-11

Burgess, C. M., Gianotti, A., Gruzdev, N., Holah, J., Knøchel, S., Lehner, A., et al. (2016). The response of foodborne pathogens to osmotic and desiccation stresses in the food chain. Int. J. Food Microbiol. 16, 37-53. doi: 10.1016/j. ijfoodmicro.2015.12.014

Casino, P., Rubio, V., and Marina, A. (2010). The mechanism of signal transduction by two-component systems. Curr. Opin. Struct. Biol. 20, 763-771. doi: 10.1016/j.sbi.2010.09.010
Centers of Disease Control and Prevention (CDC) (1999). Update: multistate outbreak of listeriosis-United States, 1998-1999. MMWR Morb. Mortal. Wkly Rep. 47:1117.

Centers of Disease Control and Prevention (CDC) (2000). Multistate outbreak of listeriosis-United States, 2000. MMWR Morb. Mortal. Wkly Rep. 49:1129

Centers of Disease Control and Prevention (CDC) (2002). Public health dispatch: outbreak of listeriosis-Northeastern United States, 2002. MMWR Morb. Mortal. Wkly Rep. Available at: https://www.cdc.gov/mmwr/preview/mmwrhtml/ mm5142a3.html (Accessed April 1, 2021). 51, 950-951.

Centers of Disease Control and Prevention (CDC) (2012a). Timeline of events: multistate outbreak of listeriosis linked to whole cantaloupes from Jensen Farms, Colorado. Available at: https://www.cdc.gov/listeria/outbreaks/ cantaloupes-jensen-farms/timeline.html (Accessed April 12, 2021).

Centers of Disease Control and Prevention (CDC) (2012c). Multistate outbreak of Listeriosis linked to crave brothers farmstead cheeses (Final Update). Available at: https://www.cdc.gov/listeria/outbreaks/cheese-07-13/index.html (Accessed April 1, 2021).

Centers of Disease Control and Prevention (CDC) (2015b). Multistate outbreak of Listeriosis linked to soft cheeses distributed by Karoun Dairies, Inc (Final Update). Available at: https://www.cdc.gov/listeria/outbreaks/softcheeses-09-15/index.html (Accessed March 30, 2021).

Centers of Disease Control and Prevention (CDC) (2015c). Multistate outbreak of listeriosis linked to commercially produced, prepackaged caramel apples made From Bidart Bros. Apples (Final Update); Centers for Disease Control and Prevention: Atlanta, GA, USA, 2015. Available at: https://www.cdc.gov/ listeria/outbreaks/caramel-apples-12-14/index.html (Accessed March 25, 2021).

Centers of Disease Control and Prevention (CDC) (2016a). Multistate outbreak of listeriosis linked to raw milk produced by miller's organic farm in Pennsylvania (Final Update). Available at: https://www.cdc.gov/listeria/ outbreaks/raw-milk-03-16/index.html (Accessed March 30, 2021).

Centers of Disease Control and Prevention (CDC) (2016b). Multistate Outbreak of Listeriosis Linked to Frozen Vegetables (Final Update); Centers for Disease Control and Prevention: Atlanta, GA, USA, 2016. Available at: https://www.cdc.gov/listeria/outbreaks/frozen-vegetables-05-16/ index.html (Accessed March 30, 2021).

Centers of Disease Control and Prevention (CDC) (2016c). Multistate Outbreak of Listeriosis Linked to Packaged Salads Produced at Springfield, Ohio Dole Processing Facility (Final Update); Centers for Disease Control and Prevention: Atlanta, GA, USA, 2016. Available at: https://www.cdc.gov/listeria/outbreaks/ bagged-salads-01-16/index.html (Accessed March 30, 2021).

Centers of Disease Control and Prevention (CDC) (2017). Multistate Outbreak of Listeriosis Linked to Soft Raw Milk Cheese Made by Vulto Creamery (Final Update); Centers for Disease Control and Prevention: Atlanta, GA, USA, 2017. Available at: https://www.cdc.gov/listeria/outbreaks/softcheese-03-17/index.html (Accessed April 1, 2021).

Centers of Disease Control and Prevention (CDC) (2018). Outbreak of Listeria Infections Linked to Deli Ham (Final Update); Centers for Disease Control and Prevention: Atlanta, GA, USA, 2018. Available at: https://www.cdc.gov/ listeria/outbreaks/countryham-10-18/index.html (Accessed April 1, 2021).

Centers of Disease Control and Prevention (CDC) (2019a). Outbreak of Listeria Infections Linked to Deli-Sliced Meats and Cheeses; Centers for Disease Control and Prevention: Atlanta, GA, USA, 2019. Available at: https://www.cdc.gov/ listeria/outbreaks/deliproducts-04-19/index.html (Accessed April 1, 2021).

Centers of Disease Control and Prevention (CDC) (2019b). Outbreak of Listeria Infections Linked to Pork Products. Available at: https://www.cdc.gov/listeria/ outbreaks/porkproducts-11-18/index.html (Accessed April 1, 2021).

Centers of Disease Control and Prevention (CDC) (2020a). Outbreak of Listeria infections linked to hard-boiled eggs. Available at: https://www.cdc.gov/ listeria/outbreaks/eggs-12-19/index.html (Accessed April 1, 2021).

Centers of Disease Control and Prevention (CDC) (2020b). Outbreak of Listeria infections linked to enoki mushrooms. Available at: https://www.cdc.gov/ listeria/outbreaks/enoki-mushrooms-03-20/index.html (Accessed April 1, 2021).

Centers of Disease Control and Prevention (CDC) (2021a). Outbreak of Listeria Infections Linked to Deli Meats. Available at: https://www.cdc.gov/listeria/ outbreaks/delimeat-10-20/index.html (Accessed April 1, 2021).

Centers of Disease Control and Prevention (CDC) (2021b). Listeria Outbreak Linked to Queso Fresco Made by El Abuelito Cheese Inc. Available at: 
https://www.cdc.gov/listeria/outbreaks/hispanic-soft-cheese-02-21/index.html (Accessed April 1, 2021).

Centers of Disease Control and Prevention (CDC) (2012b). Multistate outbreak of listeriosis linked to imported frescolina marte brand ricotta salata cheese (Final Update); Centers for Disease Control and Prevention: Atlanta, GA, USA. Available at: https://www.cdc.gov/listeria/outbreaks/cheese-09-12/index. html (Accessed April 1, 2021).

Centers of Disease Control and Prevention (CDC) (2015a). Multistate outbreak of listeriosis linked to blue bell creameries products (Final Update); Centers for Disease Control and Prevention: Atlanta, GA, USA. Available at: https://www.cdc.gov/listeria/outbreaks/ice-cream-03-15/index.html (Accessed March 30, 2021).

Chan, Y. C., Raengpradub, S., Boor, K. J., and Wiedmann, M. (2007). Microarraybased characterization of the Listeria monocytogenes cold regulon in log- and stationary-phase cells. Appl. Environ. Microbiol. 73, 6484-6498. doi: 10.1128/ AEM.00897-07

Chihib, N.-E., da Silva, M. R., Delattre, G., Laroche, M., and Federighi, M. (2003). Different cellular fatty acid pattern behaviours of two strains of Listeria monocytogenes Scott A and CNL 895807 under different temperature and salinity conditions. FEMS Microbiol. Lett. 218, 155-160. doi: 10.1111/ j.1574-6968.2003.tb11512.x

Chikindas, M. L., Weeks, R., Drider, D., Chistyakov, V. A., and Dicks, L. M. T. (2018). Functions and emerging applications of bacteriocins. Curr. Opin. Biotechnol. 49, 23-28. doi: 10.1016/j.copbio.2017.07.011

Christiansen, J. K., Nielsen, J. S., Ebersbach, T., Valentin-Hansen, P., Sogaard-Andersen, L., and Kallipolitis, B. H. (2006). Identification of small Hfq-binding RNAs in Listeria monocytogenes. RNA 12, 1383-1396. doi: 10.1261/rna.49706

Collins, B., Curtis, N., Cotter, P. D., Hill, C., and Ross, R. P. (2010b). The $\mathrm{ABC}$ transporter AnrAB contributes to the innate resistance of Listeria monocytogenes to nisin, bacitracin, and various $\beta$-lactam antibiotics. Antimicrob. Agents Chemother. 54, 4416-4423. doi: 10.1128/AAC.00503-10

Collins, B., Guinane, C. M., Cotter, P. D., Hill, C., and Ross, P. R. (2012). Assessing the contributions of the lias histidine kinase to the innate resistance of Listeria monocytogenes to nisin, cephalosporins, and disinfectants. Appl. Environ. Microbiol. 78, 2923-2929. doi: 10.1128/AEM.07402-11

Collins, B., Joyce, S., Hill, C., Cotter, P. D., and Ross, R. P. (2010a). TelA contributes to the innate resistance of Listeria monocytogenes to nisin and other cell wallacting antibiotics. Antimicrob. Agents Chemother. 54, 4658-4663. doi: 10.1128/AAC.00290-10

Cotter, P. D., Ryan, S., Gahan, C. G., and Hill, C. (2005). Presence of GadD1 glutamate decarboxylase in selected Listeria monocytogenes strains is associated with an ability to grow at low pH. Appl. Environ. Microbiol. 71, 2832-2839. doi: 10.1128/AEM.71.6.2832-2839.2005

Dawson, S. J., Evans, M. R. W., Willby, D., Bardwell, J., Chamberlain, N., and Lewis, D. A. (2006). Listeria outbreak associated with sandwich consumption from a hospital retail shop. Euro Surveill. 11, 89-91.

Desmond, E. (2006). Reducing salt: a challenge for the meat industry. Meat Sci. 74, 188-196. doi: 10.1016/j.meatsci.2006.04.014

Deutscher, J., Moussan Désirée Aké, F., Zebre, A., Nguyen Cao, T., Kentache, T., Mai Ma Pham, Q., et al. (2014). "Carbohydrate utilization by Listeria monocytogenes and its influence on virulence gene expression," in Listeria monocytogenes: Food sources, prevalence and management strategies. ed. Edmund C. Hambrick. (Hauppauge, New York, USA: Nova Science Publishers), 49-76.

Duché, O., Trémoulet, F., Glaser, P., and Labadie, J. (2002). Salt stress proteins induced in Listeria monocytogenes. Appl. Environ. Microbiol. 68, 1491-1498. doi: 10.1128/AEM.68.4.1491-1498.2002

Dussurget, O., Dumas, E., Archambaud, C., Chafsey, I., Chambon, C., Hébraud, M., et al. (2005). Listeria monocytogenes ferritin protects against multiple stresses and is required for virulence. FEMS Microbiol. Lett. 250, 253-261. doi: 10.1016/j.femsle.2005.07.015

Duze, S. T., Marimani, M., and Patel, M. (2021). Tolerance of Listeria monocytogenes to biocides used in food processing environments. Food Microbiol. 97:103758. doi: $10.1016 /$ j.fm.2021.103758

Efenberger-Szmechtyk, M., Gałązka-Czarnecka, I., Otlewska, A., Czyżowska, A., and Nowak, A. (2021). Aronia melanocarpa (Michx.) Elliot, Chaenomeles superba Lindl. And Cornus mas L. leaf extracts as natural preservatives for pork meat products. Molecules 26:3009. doi: 10.3390/molecules 26103009
Elhanafi, D., Dutta, V., and Kathariou, S. (2010). Genetic characterization of plasmid associated benzalkonium chloride resistance determinants in a Listeria monocytogenes strain from the 1998-1999 outbreak. Appl. Environ. Microbiol. 76, 8231-8238. doi: 10.1128/AEM.02056-10

Ells, T. C., and Truelstrup Hansen, L. (2011). Increased thermal and osmotic stress resistance in Listeria monocytogenes 568 grown in the presence of trehalose due to inactivation of the phosphotrehalaseencoding gene treA. Appl. Environ. Microbiol. 77, 6841-6851. doi: 10.1128/AEM.00757-11

European Centre for Disease Prevention and Control (ECDC) (2018a). Epidemiological update: multi-country outbreak of Listeria monocytogenes serogroup IVb, multi-locus sequence type 6 infections. Available at: https://www.ecdc.europa.eu/en/news-events/epidemiological-update-multicountry-outbreak-listeria-monocytogenes-serogroup-ivb (Accessed March 20, 2021).

European Centre for Disease Prevention and Control (ECDC) (2018b). Multicountry outbreak of Listeria monocytogenes infections linked to consumption of salmon products. Available at: https://www.ecdc.europa.eu/en/news-events/ multi-country-outbreak-listeria-monocytogenes-infections-linkedconsumption-salmon (Accessed March 20, 2021).

European Centre for Disease Prevention and Control (ECDC) (2019a). Rapid outbreak assessment: Multi-country outbreak of Listeria monocytogenes sequence type 6 infections linked to ready-to-eat meat products. Available at: https://www.ecdc.europa.eu/en/publications-data/rapid-outbreakassessment-multi-country-outbreak-listeria-monocytogenes-sequence (Accessed March 20, 2021).

European Centre for Disease Prevention and Control (ECDC) (2019b). Multicountry outbreak of Listeria monocytogenes clonal complex 8 infections linked to consumption of cold-smoked fish products. Available at: https:// www.ecdc.europa.eu/en/publications-data/multi-country-outbreak-listeriamonocytogenes-fish-products (Accessed March 20, 2021).

Faezi-Ghasemi, M., and Kazemi, S. (2015). Effect of sub-lethal environmental stresses on the cell survival and antibacterial susceptibility of Listeria monocytogenes PTCC1297. Zahedan J. Res. Med. Sci. 17, 1-6.

Ferreira, A., Sue, D., O'Byrne, C. P., and Boor, K. J. (2003). Role of Listeria monocytogenes $\sigma^{B}$ in survival of lethal acidic conditions and in the acquired acid tolerance response. Appl. Environ. Microbiol. 69, 2692-2698. doi: 10.1128/ AEM.69.5.2692-2698.2003

Fox, E. M., Leonard, N., and Jordan, K. (2011). Physiological and transcriptional characterization of persistent and nonpersistent Listeria monocytogenes isolates. Appl. Environ. Microbiol. 77, 6559-6569. doi: 10.1128/ AEM.05529-11

Fraqueza, M. J., Laranjo, M., Elias, M., and Patarata, L. (2021). Microbiological hazards associated with salt and nitrite reduction in cured meat products: control strategies based on antimicrobial effect of natural ingredients and protective microbiota. Curr. Opin. Food Sci. 38, 32-39. doi: 10.1016/j. cofs.2020.10.027

Gaballa, A., Guariglia-Oropeza, V., Wiedmann, M., and Boor, K. J. (2019). Cross talk between SigB and PrfA in Listeria monocytogenes facilitates transitions between extra- and intracellular environments. Microbiol. Mol. Biol. Rev. 83, e00034-e00019. doi: 10.1128/MMBR.00034-19

Gandhi, M., and Chikindas, L. M. (2007). Listeria: A foodborne pathogen that knows how to survive. Int. J. Food Microbiol. 113, 1-15. doi: 10.1016/j. ijfoodmicro.2006.07.008

Gao, R., and Stock, A. M. (2009). Biological insights from structures of twocomponent proteins. Annu. Rev. Microbiol. 63, 133-154. doi: 10.1146/annurev. micro.091208.073214

Gaul, L. K., Farag, N. H., Shim, T., Kingsley, M. A., Silk, B. J., and Hyytia-Trees, E. (2012). Hospital-acquired listeriosis outbreak caused by contaminated diced celery-Texas, 2010. Clin. Infect. Dis. 56, 20-26. doi: $10.1093 / \mathrm{cid} / \mathrm{cis} 817$

Giotis, E. S., Muthaiyan, A., Natesan, S., Wilkinson, B. J., Blair, I. S., and McDowell, D. A. (2010). Transcriptome analysis of alkali shock and alkali adaptation in Listeria monocytogenes 10403S. Foodborne Pathog. Dis. 7, 1147-1157. doi: 10.1089/fpd.2009.0501

Hadorn, K., Hächler, H., Schaffner, A., and Kayser, F. H. (1993). Genetic characterization of plasmid-encoded multiple antibiotic resistance in a strain of Listeria monocytogenes causing endocarditis. Eur. J. Hum. Genet. 12, 928-937. doi: 10.1007/BF01992167 
Harvey, J., and Gilmour, A. (2001). Characterization of recurrent and sporadic Listeria monocytogenes isolates from raw milk and nondairy foods by pulsedfield gel electrophoresis, monocin typing, plasmid profiling, and cadmium and antibiotic resistance determination. Appl. Environ. Microbiol. 67, 840-847. doi: 10.1128/AEM.67.2.840-847.2001

Haubert, L., Zehetmeyr, M. L., and da Silva, W. P. (2019). Resistance to benzalkonium chloride and cadmium chloride in Listeria monocytogenes isolates from food and foodprocessing environments in southern Brazil. Can. J. Microbiol. 65, 429-435. doi: 10.1139/cjm-2018-0618

Hingston, P., Brenner, T., Hansen, L. T., and Wan, S. (2019). Comparative analysis of Listeria monocytogenes plasmids and expression levels of plasmidencoded genes during growth under salt and acid stress conditions. Toxins 11:426. doi: 10.3390/toxins11070426

Hingston, P., Chen, J., Dhillon, B. K., Laing, C., Bertelli, C., Gannon, V., et al. (2017). Genotypes associated with Listeria monocytogenes isolates displaying impaired or enhanced tolerances to cold, salt, acid, or desiccation stress. Front. Microbiol. 8:369. doi: 10.3389/fmicb.2017.00369

Hurley, D., Luque-Sastre, L., Parker, C. T., Huynh, S., Eshwar, A. K., Nguyen, S. V., et al. (2019). Whole-genome sequencing-based characterization of 100 Listeria monocytogenes isolates collected from food processing environments over a four-year period. $m$ Sphere 4, e00252-e00219. doi: 10.1128/mSphere.00252-19

Jiang, X., Yu, T., Xu, Y., Wang, H., Korkeala, H., and Shi, L. (2019). MdrL, a major facilitator superfamily efflux pump of Listeria monocytogenes involved in tolerance to benzalkonium chloride. Appl. Microbiol. Biotechnol. 103, 1339-1350. doi: 10.1007/s00253-018-9551-y

Kocaman, N., and Sarimehmetoğlu, B. (2016). Stress responses of Listeria monocytogenes. Ankara Üniv Vet Fak Derg. 63, 421-427.

Koutsoumanis, K. P., Kendall, P. A., and Sofos, J. N. (2003). Effect of food processing-related stresses on acid tolerance of Listeria monocytogenes. Appl. Environ. Microbiol. 69, 7514-7516. doi: 10.1128/AEM.69.12.7514-7516.2003

Kovacevic, J., Ziegler, J., Walecka-Zacharska, E., Reimer, A., Kitts, D. D., and Gilmour, M. W. (2016). Tolerance of Listeria monocytogenes to quaternary ammonium sanitizers is mediated by a novel efflux pump encoded by emrE. Appl. Environ. Microbiol. 82, 939-953. doi: 10.1128/AEM.03741-15

Kremer, P. H. C., Lees, J. A., Koopmans, M. M., Ferwerda, B., Arends, A. W. M., Feller, M. M., et al. (2017). Benzalkonium tolerance genes and outcome in Listeria monocytogenes meningitis. Clin. Microbiol. Infect. 23, 265.e1-265. e7. doi: 10.1016/j.cmi.2016.12.008 e1-265.e7

Kropac, A. C., Eshwar, A. K., Stephan, R., and Tasara, T. (2019). New insights on the role of the pLMST6 plasmid in Listeria monocytogenes biocide tolerance and virulence. Front. Microbiol. 10:1538. doi: 10.3389/fmicb. 2019.01538

Lee, J. H., Jeong, K. W., and Kim, Y. M. (2012). Purification and structural characterization of cold shock protein from Listeria monocytogenes. Bull. Kor. Chem. Soc. 33, 2508-2512. doi: 10.5012/bkcs.2012.33.8.2508

Lianou, A., and Sofos, J. N. (2007). A review of the incidence and transmission of Listeria monocytogenes in ready-to-eat products in retail and food service environments. J. Food Prot. 70, 2172-2198. doi: 10.4315/0362-028X-70.9.2172

Liu, Y., Orsi, R. H., Gaballa, A., Wiedmann, M., Boor, K. J., and Guariglia-Oropeza, V. (2019). Systematic review of the Listeria monocytogenes $\sigma^{\mathrm{B}}$ regulon supports a role in stress response, virulence and metabolism. Future Microbiol. 14, 801-828. doi: 10.2217/fmb-2019-0072

Lou, Y., and Yousef, A. E. (1997). Adaptation to sub-lethal environmental stresses protects Listeria monocytogenes against lethal preservation factors. Appl. Environ. Microbiol. 63, 1252-1255. doi: 10.1128/AEM.63.4.1252-1255.1997

Lungu, B., Ricke, S. C., and Johnson, M. G. (2009). Growth, survival, proliferation and pathogenesis of Listeria monocytogenes under low oxygen or anaerobic conditions. Anaerobe 15, 7-17. doi: 10.1016/j.anaerobe.2008.08.001

Macwana, S., and Muriana, P. M. (2012). Spontaneous bacteriocin resistance in Listeria monocytogenes as a susceptibility screen for identifying different mechanisms of resistance and modes of action by bacteriocins of lactic acid bacteria. J. Microbiol. Methods 88, 7-13. doi: 10.1016/j.mimet.2011.09.009

Manso, B., Melero, B., Stessl, B., Jaime, I., Wagner, M., Rovira, J., et al. (2020). The response to oxidative stress in Listeria monocytogenes is temperature dependent. Microorganisms 8:521. doi: 10.3390/microorganisms8040521

Mastronicolis, S. K., Berberi, A., Diakogiannis, I., Petrova, E., Kiaki, I., Baltzi, T., et al. (2010). Alteration of the phospho- or neutral lipid content and fatty acid composition in Listeria monocytogenes due to acid adaptation mechanisms for hydrochloric, acetic and lactic acids at $\mathrm{pH} 5.5$ or benzoic acid at neutral pH. Antonie Van Leeuwenhoek 98, 307-316. doi: 10.1007/ s10482-010-9439-z

Mata, M. T., Baquero, F., and P'erez-Díaz, J.C., (2000). A multidrug efflux transporter in Listeria monocytogenes. FEMS Microbiol. Lett. 15, 185-188. doi: 10.1016/S0378-1097(00)00199-3

Matereke, L. T., and Okoh, A. I. (2020). Listeria monocytogenes virulence, antimicrobial resistance and environmental persistence: a review. Pathogens 9:528. doi: 10.3390/pathogens 9070528

McLauchlin, J., Hampton, M. D. D., Shah, S., Threlfall, E. J. J., Wieneke, A. A. A., and Curtis, G. D. W. D. W. (1997). Subtyping of Listeria monocytogenes on the basis of plasmid profiles and arsenic and cadmium susceptibility. $J$. Appl. Microbiol. 83, 381-388. doi: 10.1046/j.1365-2672.1997.00238.x

Meier, A. B., Guldimann, C., Markkula, A., Pöntinen, A., Korkeala, H., and Tasara, T. (2017). Comparative phenotypic and genotypic analysis of Swiss and Finnish Listeria monocytogenes isolates with respect to benzalkonium chloride resistance. Front. Microbiol. 8:397. doi: 10.3389/fmicb.2017.00397

Melo, J., Andrew, P. W., and Faleiro, M. L. (2015). Listeria monocytogenes in cheese and the dairy environment remains a food safety challenge: the role of stress responses. Food Res. Int. 67, 75-90. doi: 10.1016/j. foodres.2014.10.031

Mendum, M. L., and Smith, L. T. (2002). Characterization of glycine betaine porter I from Listeria monocytogenes and its roles in salt and chill tolerance. Appl. Environ. Microbiol. 68, 813-819. doi: 10.1128/AEM.68.2.813-819.2002

Miladi, H., Elabed, H., Slama, R. B., Rhim, A., and Bakhrouf, A. (2017). Molecular analysis of the role of osmolyte transporters opuCA and betL in Listeria monocytogenes after cold and freezing stress. Arch. Microbiol. 199, 259-265. doi: 10.1007/s00203-016-1300-y

Minarovicova, J., Veghova, A., Mikulasova, M., Chovanova, R., Soltys, K., Drahovska, H., et al. (2018). Benzalkonium chloride tolerance of Listeria monocytogenes strains isolated from a meat processing facility is related to presence of plasmidborne bcrABC cassette. Int. J. Gen. Mol. Microbiol. 111, 1913-1923. doi: 10.1007/s10482-018-1082-0

Ming, X., and Daeschel, M. A. (1993). Nisin resistance of foodborne bacteria and the specific resistance responses of Listeria monocytogenes Scott A. J. Food Prot. 56, 944-948. doi: 10.4315/0362-028X-56.11.944

Mohammed, A. N., Abdel, S., and Abdel, A. (2017). Research article ecological study on Listeria monocytogenes and the extent of its resistance to different disinfectants in dairy farm for improving animal health. Asian J. Anim. Vet. Adv. 12, 302-310. doi: 10.3923/ajava.2017.302.310

Møretrø, T., Schirmer, B. C. T., Heir, E., Fagerlund, A., Hjemli, P., and Langsrud, S. (2017). Tolerance to quaternary ammonium compound disinfectants may enhance growth of Listeria monocytogenes in the food industry. Int. J. Food Microbiol. 241, 215-224. doi: 10.1016/j.ijfoodmicro.2016.10.025

Naditz, A. L., Dzieciol, M., Wagner, M., and Schmitz-Esser, S. (2019). Plasmids contribute to food processing environment-associated stress survival in three Listeria monocytogenes ST121, ST8, and ST5 strains. Int. J. Food Microbiol. 299, 39-46. doi: 10.1016/j.ijfoodmicro.2019.03.016

Nair, S., Milohanic, E., and Berche, P. (2000). ClpC ATPase is required for cell adhesion and invasion of Listeria monocytogenes. Infect. Immun. 68, 7061-7068. doi: 10.1128/IAI.68.12.7061-7068.2000

NicAogain, K., and O'Byrne, C. P. (2016). The role of stress and stress adaptations in determining the fate of the bacterial pathogen Listeria monocytogenes in the food chain. Front. Microbiol. 7:1865. doi: 10.3389/ fmicb.2016.01865

Noll, M., Trunzer, K., Vondran, A., Vincze, S., Dieckmann, R., Al Dahouk, S., et al. (2020). Benzalkonium chloride induces a VBNC state in Listeria monocytogenes. Microorganisms 8:184. doi: 10.3390/microorganisms8020184

O'Byrne, C. P., and Karatzas, K. A. (2008). The role of sigmaB $\left(\sigma^{\mathrm{B}}\right)$ in the stress adaptations of Listeria monocytogenes: overlaps between stress adaptation and virulence. Adv. Appl. Microbiol. 65, 115-140. doi: 10.1016/S00652164(08)00605-9

O'Neil, S. H., and Marquis, H. (2006). Listeria monocytogenes flagella are used for motility, not as adhesins to increase host cell invasion. Infect. Immun. 74, 6675-6681. doi: 10.1128/IAI.00886-06

Orsi, R. H., Chaturongakul, S., Oliver, H. F., Ponnala, L., Gaballa, A., and Wiedmann, M. (2021). Alternative factors regulate overlapping as well as distinct stress response and metabolic functions in Listeria monocytogenes under stationary phase stress condition. Pathogens 10:411. doi: 10.3390/ pathogens 10040411 
Ortiz, S., López-Alonso, V., Rodríguez, P., and Martínez-Suárez, J. V. (2016). The connection between persistent, disinfectant-resistant Listeria monocytogenes strains from two geographically separate Iberian pork processing plants: evidence from comparative genome analysis. Appl. Environ. Microbiol. 82, 308-317. doi: 10.1128/AEM.02824-15

Palma, F., Brauge, T., Radomski, N., Mallet, L., Felten, A., Mistou, M. Y., et al. (2020). Dynamics of mobile genetic elements of Listeria monocytogenes persisting in ready-to-eat seafood processing plants in France. BMC Genomics 21:130. doi: $10.1186 / \mathrm{s} 12864-020-6544-\mathrm{x}$

Pöntinen, A., Aalto-Araneda, M., Lindström, M., and Korkeala, H. (2017). Heat resistance mediated by pLM58 plasmid-borne ClpL in Listeria monocytogenes. mSphere 2, e00364-e00317. doi: 10.1128/mSphere.00364-17

Premaratne, R. J., Lin, W., and Johnson, E. A. (1991). Development of an improved chemically defined minimal medium for Listeria monocytogenes. Appl. Environ. Microbiol. 57, 3046-3048. doi: 10.1128/aem.57.10.30463048.1991

Rakic-Martinez, M., Drevets, D. A., Dutta, V., Katic, V., and Kathariou, S. (2011). Listeria monocytogenes strains selected on ciprofloxacin or the disinfectant benzalkonium chloride exhibit reduced susceptibility to ciprofloxacin, gentamicin, benzalkonium chloride, and other toxic compounds. Appl. Environ. Microbiol. 77, 8714-8721. doi: 10.1128/ AEM.05941-11

Ratani, S. S., Siletzky, R. M., Dutta, V., Yildirim, S., Osborne, J. A., Lin, W., et al. (2012). Heavy metal and disinfectant resistance of Listeria monocytogenes from foods and food processing plants. Appl. Environ. Microbiol. 78, 6938-6945. doi: 10.1128/AEM.01553-12

Rea, R., Hill, C., and Gahan, C. G. (2005). Listeria monocytogenes PerR mutants display a small-colony phenotype, increased sensitivity to hydrogen peroxide, and significantly reduced murine virulence. Appl. Environ. Microbiol. 71, 8314-8322. doi: 10.1128/AEM.71.12.8314-8322.2005

Renier, S., Hebraud, M., and Desvaux, M. (2011). Molecular biology of surface colonization by Listeria monocytogenes: an additional facet of an opportunistic gram-positive foodborne pathogen. Environ. Microbiol. 13, 835-850. doi: 10.1111/j.1462-2920.2010.02378.x

Ribeiro, V. B., Mujahid, S., Orsi, R. H., Bergholz, T. M., Wiedmann, M., Boor, K. J., et al. (2014). Contributions of $\sigma^{\mathrm{B}}$ and PrfA to Listeria monocytogenes salt stress under food relevant conditions. Int. J. Food Microbiol. 177, 98-108. doi: 10.1016/j.ijfoodmicro.2014.02.018

Ríos Colombo, N. S., Chalón, M. C., Navarro, S. A., and Bellomio, A. (2018). Pediocin-like bacteriocins: new perspectives on mechanism of action and immunity. Curr. Genet. 64, 345-351. doi: 10.1007/s00294017-0757-9

Ripio, M. T., Vaèzquez-Boland, J.-A., Vega, Y., Nair, S., and Berche, P. (1998). Evidence for expressional crosstalk between the central virulence regulator PrfA and the stress response mediator $\mathrm{ClpC}$ in Listeria monocytogenes. FEMS Microbiol. Lett. 158, 45-50. doi: 10.1111/j.15746968.1998.tb12798.x

Roedel, A., Dieckmann, R., Brendebach, H., Hammerl, J. A., Kleta, S., Noll, M., et al. (2019). Biocide-tolerant Listeria monocytogenes isolates from German food production plants do not show cross-resistance to clinically relevant antibiotics. Appl. Environ. Microbiol. 85, e01253-e01219. doi: 10.1128/ AEM.01253-19

Ruusunen, M., and Puolanne, E. (2005). Reducing sodium intake from meat products. Meat Sci. 70, 531-541. doi: 10.1016/j.meatsci.2004.07.016

Ryan, S., Begley, M., Gahan, C. G. M., and Hill, C. (2009). Molecular characterization of the arginine deiminase system in Listeria monocytogenes: regulation and role in acid tolerance. Environ. Microbiol. 11, 432-445. doi: $10.1111 / j .1462-2920.2008 .01782 . x$

Ryan, S., Hill, C., and Gahan, C. G. (2008). Acid stress responses in Listeria monocytogenes. Adv. Appl. Microbiol. 65, 67-91. doi: 10.1016/S00652164(08)00603-5

Schmid, B., Klumpp, J., Raimann, E., Loessner, M. J., Stephan, R., and Tasara, T. (2009). Role of cold shock proteins in growth of Listeria monocytogenes under cold and osmotic stress conditions. Appl. Environ. Microbiol. 75, 1621-1627. doi: 10.1128/AEM.02154-08

Shan, B., Cai, Y.-Z., Brooks, J. D., and Corke, H. (2009). Antibacterial and antioxidant effects of five spice and herb extracts as natural preservatives of raw pork. J. Sci. Food Agric. 89, 1879-1885. doi: 10.1002/ jsfa.3667
Silva, C. C. G., Silva, S. P. M., and Ribeiro, S. C. (2018). Application of bacteriocins and protective cultures in dairy food preservation. Front. Microbiol. 9:594. doi: 10.3389/fmicb.2018.00594

Sleator, R. D., and Hill, C. (2002). Bacterial osmoadaptation: the role of osmolytes in bacterial stress and virulence. FEMS Microbiol. Rev. 26, 49-71. doi: 10.1111/j.1574-6976.2002.tb00598.x

Smelt, J. P. P. M., and Brul, S. (2014). Thermal inactivation of microorganisms. Crit. Rev. Food Sci. Nutr. 54, 1371-1385. doi: 10.1080/10408398.2011.637645

Smith, J. L., Liu, Y., and Paoli, G. C. (2013). How does Listeria monocytogenes combat acid conditions? Can. J. Microbiol. 59, 141-152. doi: 10.1139/cjm-2012-0392

Smith, A. M., Tau, N. P., Smouse, S. L., Allam, M., Ismail, A., Ramalwa, N. R., et al. (2019). Outbreak of Listeria monocytogenes in South Africa, 2017-2018: laboratory activities and experiences associated with whole-genome sequencing analysis of isolates. Foodborne Pathog. Dis. 16, 524-530. doi: 10.1089/ fpd.2018.2586

Soares, C. A., and Knuckley, B. (2016). Mechanistic studies of the agmatine deiminase from Listeria monocytogenes. Biochem. J. 473, 1553-1561. doi: 10.1042/BCJ20160221

Soni, K. A., Nannapaneni, R., and Tasara, T. (2011). The contribution of transcriptomic and proteomic analysis in elucidating stress adaptation responses of Listeria monocytogenes. Foodborne Pathog. Dis. 8, 842-852. doi: 10.1089/ fpd.2010.0746

Stoll, R., and Goebel, W. (2010). The major PEP-phosphotransferase systems (PTSs) for glucose, mannose and cellobiose of Listeria monocytogenes, and their significance for extra- and intracellular growth. Microbiology 156, 1069-1083. doi: 10.1099/mic.0.034934-0

Tapia, N. C., Dorey, A. L., Gahan, C. G. M., den Besten, H. M. W., O'Byrne, C. P., and Abee, T. (2020). Different carbon sources result in differential activation of sigma $\mathrm{B}$ and stress resistance in Listeria monocytogenes. Int. J. Food Microbiol. 320:108504. doi: 10.1016/j. ijfoodmicro.2019.108504

Thedieck, K., Hain, T., Mohamed, W., Tindall, B. J., Nimtz, M., Chakraborty, T., et al. (2006). The MprF protein is required for lysinylation of phospholipids in listerial membranes and confers resistance to cationic antimicrobial peptides (CAMPs) on Listeria monocytogenes. Mol. Microbiol. 62, 1325-1339. doi: $10.1111 /$ j.1365-2958.2006.05452

Tongnuanchan, P., and Benjakul, S. (2014). Essential oils: extraction, bioactivities, and their uses for food preservation. J. Food Sci. 79, 1231-1249. doi: 10.1111/1750-3841.12492

Van Houdt, R., and Michiels, C. W. (2010). Biofilm formation and the food industry, a focus on the bacterial outer surface. J. Appl. Microbiol. 109, 1117-1131. doi: 10.1111/j.1365-2672.2010.04756.x

Werbrouck, H., Vermeulen, A., Van Coillie, E., Messens, W., Herman, L., Devlieghere, F., et al. (2009). Influence of acid stress on survival, expression of virulence genes and invasion capacity into Caco-2 cells of Listeria monocytogenes strains of different origins. Int. J. Food Microbiol. 134, 140-146. doi: 10.1016/j.ijfoodmicro.2009.03.022

World Health Organization (WHO). (2018a). Listeriosis. Available at: https:// www.who.int/news-room/fact-sheets/detail/listeriosis (Accessed April 17, 2021).

World Health Organization (WHO) (2018b). Listeriosis- Spain. Available at: https://www.who.int/csr/don/16-september-2019-listeriosis-spain/en/ (Accessed April 17, 2021).

World Health Organization (WHO). (2018c). Listeriosis-Australia. Available at: https://www.who.int/csr/don/09-april-2018-listeriosis-australia/en/ (Accessed April 17, 2021).

Wouters, J. A., Hain, T., Darji, A., Hüfner, E., Wemekamp-Kamphuis, H., Chakraborty, T., et al. (2005). Identification and characterization of di- and tripeptide transporter DtpT of Listeria monocytogenes EGD-e. Appl. Environ. Microbiol. 71, 5771-5778. doi: 10.1128/AEM.71.10.5771-5778.2005

Wu, S., Yu, P.-L., Wheeler, D., and Flint, S. (2018). Transcriptomic study on persistence and survival of Listeria monocytogenes following lethal treatment with nisin. J. Glob. Antimicrob. Resist. 15, 25-31. doi: 10.1016/j. jgar.2018.06.003

Yu, T., Jiang, X., Zhang, Y., Ji, S., Gao, W., and Shi, L. (2018). Effect of benzalkonium chloride adaptation on sensitivity to antimicrobial agents and tolerance to environmental stresses in Listeria monocytogenes. Front. Microbiol. 9:2906. doi: 10.3389/fmicb.2018.02906

Zhang, H., Hu, Y., Zhou, C., Yang, Z., Wu, L., Zhu, M., et al. (2018). Stress resistance, motility and biofilm formation mediated by a $25 \mathrm{~kb}$ plasmid 
pLMSZ08 in Listeria monocytogenes. Food Control 94, 345-352. doi: 10.1016/j. foodcont.2018.07.002

Zhou, Q., Feng, X., Zhang, Q., Feng, F., Yin, X., Shang, J., et al. (2012). Carbon catabolite control is important for Listeria monocytogenes biofilm formation in response to nutrient availability. Curr. Microbiol. 65, 35-43. doi: 10.1007/ s00284-012-0125-4

Conflict of Interest: The authors declare that the research was conducted in the absence of any commercial or financial relationships that could be construed as a potential conflict of interest.

Publisher's Note: All claims expressed in this article are solely those of the authors and do not necessarily represent those of their affiliated organizations, or those of the publisher, the editors and the reviewers. Any product that may be evaluated in this article, or claim that may be made by its manufacturer, is not guaranteed or endorsed by the publisher.

Copyright (C) 2021 Wiktorczyk-Kapischke, Skowron, Grudlewska-Buda, WateckaZacharska, Korkus and Gospodarek-Komkowska. This is an open-access article distributed under the terms of the Creative Commons Attribution License (CC $B Y)$. The use, distribution or reproduction in other forums is permitted, provided the original author(s) and the copyright owner(s) are credited and that the original publication in this journal is cited, in accordance with accepted academic practice. No use, distribution or reproduction is permitted which does not comply with these terms. 